
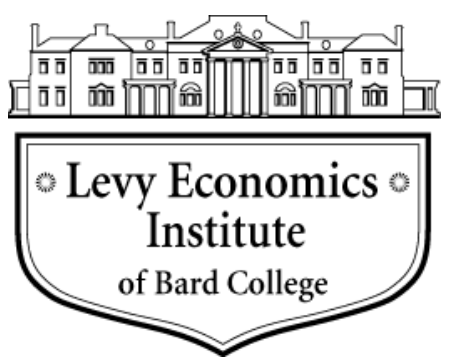

Working Paper No. 888

\title{
Gender, Socioeconomic Status, and Time Use of Married and Cohabiting Parents during the Great Recession
}

\author{
by \\ Ebru Kongar \\ Levy Economics Institute of Bard College
}

Mark Price

Keystone Research Center

April 2017

The Levy Economics Institute Working Paper Collection presents research in progress by Levy Institute scholars and conference participants. The purpose of the series is to disseminate ideas to and elicit comments from academics and professionals.

Levy Economics Institute of Bard College, founded in 1986, is a nonprofit, nonpartisan, independently funded research organization devoted to public service. Through scholarship and economic research it generates viable, effective public policy responses to important economic problems that profoundly affect the quality of life in the United States and abroad.

Levy Economics Institute P.O. Box 5000

Annandale-on-Hudson, NY 12504-5000

http://www.levyinstitute.org

Copyright (C) Levy Economics Institute 2017 All rights reserved

ISSN 1547-366X 


\begin{abstract}
Using data from the 2003-14 American Time Use Survey (ATUS), this paper examines the relationship between the state unemployment rate and the time that opposite-sex couples with children spend on childcare activities, and how this varies by the socioeconomic status (SES), race, and ethnicity of the mothers and fathers. The time that mothers and fathers spend providing primary and secondary child caregiving, solo time with children, and any time spent as a family are considered. To explore the impact of macroeconomic conditions on the amount of time parents spend with children, the time-use data are combined with the state unemployment rate data from the US Bureau of Labor Statistics. The analysis finds that the time parents spend on child-caregiving activities or with their children varies with the unemployment rate in low-SES households, African-American households, and Hispanic households. Given that job losses were disproportionately high for workers with no college degree, African-Americans, and Hispanics during the Great Recession, the results suggest that the burden of household adjustment during the crisis fell disproportionately on the households most affected by the recession.
\end{abstract}

Keywords: Economics of Gender; Time Use; Economic Crises; Unpaid Labor

JEL Classifications: D13, J16, J64 


\section{INTRODUCTION}

It has been almost eight years since the official end of the Great Recession (hereafter, the recession) in June 2009, and there is now extensive research that examines its outcomes for the spheres of finance and production in the US economy. However, only a few studies to date have examined its outcomes for the sphere of household reproduction, and even fewer studies have paid attention to the roles played by gender, race, and class in these analyses. In this paper, we examine the relationships between state macroeconomic conditions and the time opposite-sex couples spent with their children over the 2003-14 period. In doing so, we aim to contribute to the rather sparse American literature that explores the gendered outcomes of the recession in the reproductive sphere, and the broader gender and macroeconomics literature that examines the two-way relationships between gender inequalities and economic crises.

It is now well established that in the productive sphere of the US economy the recession had differentiated outcomes by gender, race, ethnicity, and educational attainment. While women who maintain families lost more jobs than married men and women, on average men lost more jobs than women; African-Americans, Hispanics, and workers without a college education lost more jobs than their respective counterparts of non-Hispanic whites and workers with a college education (Albelda 2014; Grown and Tas 2010). The recovery has also been experienced differently by those of different genders, races, ethnicities, and educational attainment. For instance, while the recession officially ended in June 2009, job losses for men continued until the end of 2009, and until May 2010 for women (Hartmann, Shaw, and O'Connor 2014). Job recovery was initially slower for women - in part due to the loss of government jobs during this period - but by June 2014, women had regained all the jobs they lost in the recession and more, while men have regained about almost all (90 percent) of the jobs they lost during the recession (Hartmann, Shaw, and O'Connor 2014: 1). Evidence also shows that involuntary part-time work and other forms of underemployment increased during the recession and in its immediate aftermath, a trend also observed in the European economies most affected by the recession and austerity (Grown and Tas 2014; Karamessini and Rubery, forthcoming).

As Bianchi (2011: 13) points out, “time tends to be a 'zero-sum game,' with time devoted to any one activity increasing only if another activity suffers an equal loss." The decline in paid work 
hours due to job loss or underemployment during the recession allowed for time to be spent on other activities, albeit in a recessionary context with less household income. How does this extra time get allocated? What was the impact of time reallocation on the gender division of paid and unpaid labor during the recession? An empirical investigation of these questions in the American context became possible for the first time in 2010, when American Time Use Survey (ATUS) data, collected since 2003, became available for the course of a full business cycle. Using data from the 2003-10 ATUS, Aguiar, Hurst, and Karabarbounis (2013) explore how the "surplus time" in US labor markets during the recession was reallocated across unpaid work, leisure and personal care activities, and other categories of time use, and found that both women and men allocated more than half of their foregone paid work hours to leisure activities, and about onethird to unpaid housework and care work activities. For married or cohabiting opposite-sex parents in the US, Berik and Kongar (2013) examined the impact of the recession on gender differences in time use over the 2003-10 period through a gender lens and found evidence of an increase in mothers' paid work burden during the recession, while fathers increased the time they spent on child-caregiving activities. Morrill and Pabilonia (2015) examined the time opposite-sex married or cohabiting couples who have children spent together over the 2003-10 period and found that couples spend more time together when the state unemployment rate is low, but couples' time together increases at very high unemployment rates.

In this study, using data from the 2003-14 ATUS, we explore the relationship between macroeconomic conditions and the time opposite-sex parents spent on child-caregiving activities over the period. To capture differences by race and ethnicity, we examine our models separately for mothers and fathers who are non-Hispanic black or African-American, non-Hispanic white, or Hispanic. For brevity, we refer to non-Hispanic black or African-American mothers and fathers as "African-American" and non-Hispanic white mothers and fathers as "white." Together with Hispanic mothers and fathers, these constitute mutually exclusive categories of mothers and fathers. ${ }^{1}$ We also estimate our models separately by socioeconomic status, which we proxy by whether the father in the household has a college education. Throughout the study, we refer to households in which the father does not have a college education as "low-socioeconomic-status"

\footnotetext{
${ }^{1}$ While our full sample of mothers and fathers includes all races and ethnicities, we only report separate results for African-American, Hispanic, or white mothers and fathers, as the remaining group of mothers and fathers is too heterogeneous and the sample size is too small to allow for any meaningful interpretations of the results.
} 
(SES) households, and to their counterparts with a college education as high-SES households.

Our main findings show that the time parents, especially mothers, spend on primary childcaregiving activities is resistant to change as macroeconomic conditions worsen. However, we find considerable variation in the time spent alone with children in low-SES households, AfricanAmerican households, and Hispanic households when macroeconomic conditions change. Similarly, family time in these households is affected more by changes in state macroeconomic conditions. When the unemployment rates are high, we find evidence of an added-worker effect for white mothers, and also evidence of substitution of fathers' care for mothers' care in secondary child-caregiving activities (e.g., cooking while household children are watching TV). We observe a similar substitution in low-SES households for primary child-caregiving activities. For African-American mothers, African-American fathers, and Hispanic fathers, we find an increase in nonstandard paid work hours, which suggests increased hardship in these households when macroeconomic conditions worsen. Taken together with our findings for child-caregiving activities, these findings suggest that the time parents spend with and providing care to their children falls on households most affected by the recession in labor markets. Like the broader gender and macroeconomics literature, our findings stress the importance of examining microeconomic work-life balance questions within the broader macroeconomic context, and the importance of paying attention to the roles played by race, ethnicity, and class in these analyses.

In the rest of the paper, we first present an overview of the literature that links gender inequalities in unpaid work to macroeconomic conditions, as well as an overview of the relevant microeconomic literature on gender differences in time use. We then present our data and empirical model, which we utilize to investigate the relationship between macroeconomic conditions and gendered reallocation and reorganization of time spent caring for children over the 2003-14 period. 


\section{MACROECONOMIC CONDITIONS, GENDER, AND TIME USE}

Since the 1990s, feminist economic scholarship has developed gender-aware frameworks and models for analysis of macroeconomic phenomena and policies (Antonopoulos et al., 2013; İlkkaracan, forthcoming; Karamessini and Rubery, forthcoming; Rubery 1988, 2013). ${ }^{2}$ Elson (2010) provides such a framework for the analysis of the gender dimensions of the Great Recession - where inequalities by gender played a role in contributing to the financial crisis and the subsequent recession - as well as the subsequent policy responses that have gendered outcomes in the spheres of finance, production, and reproduction. Empirical evidence for the US is consistent with this framework. For instance, targeting of subprime lending toward single female heads of households, low-income households, and people of color - who have historically been excluded from credit markets by financial institutions - played a significant role in contributing to the financial crisis (Dymsky, Hernandez, and Mohanty 2013; Fukuda-Parr, Heintz, and Seguino 2013; Pressman 2014; Wisman and Baker 2014). Moreover, the recession had gendered outcomes in the sphere of production, primarily due to industrial and occupational segregation by gender, resulting in disproportionate job losses for men in the US, Canada, and the European countries most affected by the recession (Christensen 2015; Karamessini and Rubery, forthcoming).

Within Elson's (2010) framework, the reproductive sphere- - which includes unpaid work within the household and in communities, and paid work in public services like health and educationacts as a safety net during the recessions. In the US, for instance, Starr (2011) shows that the nonprofit emergency food system, such as food pantries and soup kitchens, alleviated some but not all of the food insecurity that arose during the recession. Unpaid household work also acts as a safety net during recessions. Given their disproportionate share in unpaid labor, economic crises may increase women's relative unpaid work burden as they compensate for the loss of household income by increasing their own production of goods and services previously purchased in the market (Benería and Feldman 1992). In the face of a male spouse's job loss, women may also take on paid work during economic crises, a phenomenon known as the "added-worker effect," leading to at least a temporary disruption and reversal of gender roles (Elson 1991, 2002; Kaya-

\footnotetext{
${ }^{2}$ For a review of these models, see Benería, Berik, and Floro (2015).
} 
Bahce and Memis 2013; Rubery 1988). There is evidence of an added-worker effect in the US, Canada, and the European economies during the Great Recession (Berik and Kongar 2013; Karamessini and Rubery, forthcoming; Şahin, Song, and Hobijn 2010; Starr 2014). However, in the US, data on the time use of household members other than the respondent to the ATUS are not available, and the impact of the recession on patterns of the within-household gender division of unpaid labor are inferred from comparisons of nationally representative trends for coupled (married or cohabiting) women and men who reside in the same household as their spouse or unmarried partner (Berik and Kongar 2013; Kaya-Bahce and Memis 2013). ${ }^{3}$

In the year 2012, 64 percent of married-couple families with children under the age of 18 were dual-income families with two employed parents (Glynn 2014: 5). About a quarter of the married mothers with earnings were the primary breadwinner in the family and 30 percent of married mothers with earnings contributed to 25-49 percent of the family income (Glynn 2014: 7). Families where only the father was employed constituted 24 percent of the married-couple families with children (henceforth father-earner families) in 2000, and 28.4 percent in 2012; these families were as likely to be at the bottom of the income distribution as they were at the top in 2012. Accordingly, as pointed out by Glynn (2014: 9), a married mother who is not an income earner is not necessarily a "wealthy housewife" who "opts out" of the labor force. Between 2000 and 2012, the percentage of dual-income parents among married-couple families with children declined by about 7 percentage points from 71 percent to 64 percent, reflecting a rise in the share of father-earner families and to a lesser extent also a rise in the share of mother-earner families. ${ }^{4}$ Hispanic mothers make up 26.4 percent of married mothers with zero earnings, while AfricanAmerican mothers make up 6 percent, reflecting the historically high labor force participation rates among African-American women and perhaps also lower average earnings for Hispanic women compared to African-American women, which discourages their entry into the labor force, especially within the US policy context where only a few policies address work-family challenges (Glynn 2014).

\footnotetext{
${ }^{3}$ Using data from 2003-10 ATUS for women and men, Aguiar, Hurst, and, Karabarbounis (2013) find that women and men reallocate their foregone paid work hours to leisure activities and unpaid work in a similar manner. In particular, women and men reallocated 50 percent of their foregone market work hours during the recession to leisure activities, 30 percent to unpaid housework, and 5 percent to child caregiving. However, they also find that men's paid work hours declined by 11 percent, while women experienced a less than 1 percent $(0.32$ percent $)$ decline in their unpaid work hours (Aguiar, Hurst, and Karabarbounis 2013: 1671).

${ }^{4}$ The share of families where only the father was employed increased by 4.3 percentage points; the percentage of families where only the mother was employed increased by 1.5 percentage points (Glynn 2014: 9).
} 
While the contribution of mothers' earnings to family income has increased over time, only a few policies in the US address the work-life conflict (Boushey 2016). The US is the only advanced economy without mandated paid parental leave. While the Family Medical Leave Act requires employers to provide job-protected leave for up to 12 weeks, this applies to businesses with at least 50 employees, and only workers who have worked for their employer for at least 1,250 hours in the last year are eligible for this benefit (US Department of Labor, n.d.). Paid parental leave may be provided by the employer in the private sector; however, only 13 percent of all workers and 6 percent of workers who are at the bottom of the wage distribution have access to paid parental leave (BLS 2016a). Rather than public provisioning of childcare services for children under the age of six, policies through tax deductions for childcare expenses encourage use of market-provided services (Anxo, et al. 2011). However, affordable, quality childcare is limited, and enrollment rates of children under the age of six in formal care or early education services is lower in the US compared to the OECD average (OECD 2016). In this work-life policy context, evidence suggests that dual-income families, especially low-income families, may try to achieve work-life balance by coordinating their work schedules, particularly with one parent working nonstandard hours (Enchautegui 2013; Presser 1995; Wright, Raley, and Bianchi 2008). In the productive sphere, African-Americans, Hispanics, and workers without a college education are more likely to have nonstandard work schedules. For African-American and Hispanic workers, this likely reflects not only an attempt to achieve work-life balance through this arrangement at the expense of family time, but also limited job opportunities due to occupational segregation by race and ethnicity in the US labor markets. ${ }^{5}$

During the recession, there is evidence of an increase in nonstandard work hours, especially for women and mothers without a college education, compared to men and fathers without a college education (Starr 2014). For instance, Enchautegui (2013) finds that among workers without a college degree, the odds of having nonstandard paid work hours increased for women relative to men during the 2008-11 period, compared to the 2004-07 period, such that over the 2008-11 period women were as likely to be working nonstandard hours as men. This might reflect lowincome women economizing on childcare expenses by being available at home to take care of

\footnotetext{
${ }^{5}$ Workers in all but one of the ten occupations with the largest shares of workers in nonstandard schedules are disproportionately black or African-American, and in all but two of them they are Hispanic (BLS 2016b). Four of these occupations - namely, registered nurses, health aides, personal-care aides, and wait staff — are traditionally female occupations where at least 70 percent of the workforce are women.
} 
children during the weekdays and working for pay during nonstandard work hours to contribute to family income, or that women without a college education are unable to find good jobs with standard hours in a recessionary context, where workers without a college education suffered more job losses (Presser 1995; Wright, Raley, and Bianchi 2008).

What we know in terms of the outcomes in the productive sphere is that when macroeconomic conditions worsened during the Great Recession, differences in unemployment rates by gender, race, ethnicity, and educational attainment widened. Between the fourth quarter of 2007 and the second quarter of 2009, the difference between the unemployment rates of men with and without a college education more than doubled, increasing from 3 percentage points to 7 percentage points. ${ }^{6}$ The difference in the unemployment rates of married white men and married African-American men more than tripled, and the difference between married Hispanic men and married white men nearly doubled. ${ }^{7}$ As Ehrenreich and Muhammad (2009) argue, the recession felt more like a depression for African-Americans who, due to a legacy of discrimination in the financial and productive spheres, are also less likely than their white counterparts to be able to absorb recessionary shocks by borrowing or relying on their savings accounts.

Morrill and Pabilonia's (2015) analysis of time use data from the 2003-10 ATUS for married mothers and fathers who live in the same household with their spouse and at least one child under age 19 shows that while the recession was associated with an increase in married mothers' total work burden relative to married fathers, this was primarily due to a large decline in fathers' paid work hours rather than an increase in mothers' unpaid work burden. Fathers whose paid work hours declined during the recession spent more time taking care of children during the recession, while mothers whose paid work hours increased seem to have protected their primary childcaregiving time, i.e., they do not find a significant decline in the mothers' primary childcaregiving time. Other findings for the 2003-10 period show that as the economy worsened,

\footnotetext{
${ }^{6}$ Authors' calculations from quarterly unemployment rate data (US Bureau of Labor Statistics, Labor Force Statistics, the Current Population Survey) for married women age 25 or over who live in households with their spouse, by race and ethnicity, for the 2003-14 period.

${ }^{7}$ These trends are not attributable to differences in human capital only. An examination of differences in employment and earnings of non-college-educated African-American men and non-college-educated white men over the 2007-09 period shows that white men without a college degree were more likely to be employed and to have higher earnings than African-American men without a college degree (Dickerson vonLockette 2014).
} 
fathers spend more solo time ${ }^{8}$ with household children in "enriching" child-caregiving activities, such as reading and playing sports with children (Morrill and Pabilonia 2012).

Previous findings in the literature for the 1991-92 recession also show that the percentage of fathers who acted as (primary or secondary) childcare providers increased significantly when their wives' hours of paid work increased during the period, and declined in the immediate aftermath of that recession (Casper and O'Connell 1998). These findings show patterns that are consistent with the increasing availability of fathers in the household due to job loss or fewer paid work hours during the period. In terms of parents' secondary child-caregiving time, during expansionary periods, microeconomic analyses of parents' child-caregiving time find that in the US and several other industrialized countries, employed mothers spend less time on child-caregiving activities than nonemployed mothers, but the difference is primarily due to less time spent with children, as well as less time engaged in secondary child-caregiving activities rather than in primary childcaregiving activities (Bianchi 2011; Connelly and Kimmel 2010; Folbre and Yoon 2007; Kalenkoski, Ribar, and Stratton 2007; Nock and Kingston 1988). Accordingly, we also explore whether the time parents spend in secondary child-caregiving activities varies with macroeconomic conditions.

While the ATUS does not collect information on the spouse or unmarried partner's time use, it does collect information on whom the respondent is with during an activity for activities other than sleeping and other forms of personal care. Using this information for 2003-10, Morrill and Pabilonia (2015) examine the relationship between (married or cohabiting, opposite-sex) couples' time together and state unemployment rates over the 2003-10 period. They find a U-shaped relationship, where couples spend more time together when the state unemployment rate is low (5 percent) compared to when the state unemployment rate is high (at around 10 percent); however, when the unemployment rate increases above 9 percent, the time couples spend together increases. They observe the same relationship when couples are with their children. To explain why couples spend less time together when the unemployment rate is between 5-10 percent, Morrill and Pabilonia (2015) explore the possibility that mothers are working nonstandard work hours when the unemployment rate is between 8 to 10 percent. Contrary to previous findings in

\footnotetext{
8 "Solo time" includes any time with child when the spouse or unmarried partner is absent. However, there may be others in the room.
} 
the literature by Connelly and Kimmel (2011), which finds no indication of a change for the expansion over the 2003-06 period, Morrill and Pabilonia (2015) find evidence of nonstandard schedules for mothers when the unemployment rate was between 8 to 10 percent over the entire 2003-10 period. $^{9}$

In this paper, we focus on the relationship between state macroeconomic conditions and the time parents spend on child-caregiving activities. Our child-caregiving variables of interest are primary child caregiving, secondary child caregiving, solo time with children, and family time (any time with child and spouse). We explore the relationships between these variables and the within-state variation in unemployment rates relative to other states, which we use as a proxy for the businesscycle effect. Our methodology is similar to Aguiar, Hurst, and Karabarbounis (2013) and Morrill and Pabilonia (2015), who use state unemployment rates as a proxy for macroeconomic conditions rather than individual-level data on employment status in order to estimate the effects of the recession.

Following Morrill and Pabilonia (2015), to explore the patterns of time use in the productive sphere, we model the relationship between time spent on paid work activities and macroeconomic conditions, and also explore patterns in work schedules by distinguishing between weekend paid work hours, paid work hours during standard hours on weekdays, and paid work hours during nonstandard hours. Variations in work schedules that are correlated with the unemployment rate might reflect difficulty in finding opportunities for employment during standard hours on weekdays when the economy worsens. Moreover, fearing job loss during hard times, households may reduce their spending on childcare services, and thus possibly parents spend more time providing child care. These possible adjustments in work-related behavior are examples of how reallocation and reorganization of time within the household during times of high unemployment affect time spent in other categories of time use. Accordingly, in our model, we explore the relationships between state unemployment rates and time use in all households regardless of the employment status of mothers, fathers, and their spouses.

\footnotetext{
${ }^{9}$ As pointed out by Morrill and Pabilonia (2015), previous findings by Connelly and Kimmel (2011) may be due to a small number of mothers living in states where the unemployment rate was high during the expansionary period of 2003-06.
} 
We expect that reallocation and reorganization will be more necessary in low-SES households compared to high-SES households, where the shock can be absorbed through dissaving and access to individual networks of support. Given the disproportionate impact of the recent recession on African-American and Hispanic households, and the segregated nature of US employment that limits job opportunities for these households, we also expect a more pronounced relationship between their time use and macroeconomic conditions compared to their white counterparts. Gendered outcomes of the recession in the productive sphere combined with different outcomes by race, ethnicity, and education will affect gendered patterns of time reallocation and reorganization in the household. Mothers and fathers in these households reallocate and reorganize time in this recessionary context, balancing child-caregiving responsibilities and paid work activities within the context of gender norms. Below, we explore these relationships for mothers and fathers by race, ethnicity, and socioeconomic status.

\section{DATA AND METHODOLOGY}

Our sample of individual-level time diary respondents from the 2003-14 ATUS data files includes women and men who reside in the same household with their opposite-sex spouse or unmarried partner and at least one child under the age of 19. For brevity, we refer to the women and men in our sample respectively as "mothers" and "fathers" and to their spouse or unmarried partner as “spouse." Following Morrill and Pabilonia (2015), we limit the sample to respondents between the

ages of 25 and 64, and exclude diaries where the respondent reported either sleeping more than 20 hours or performing health-related self-care for more than four hours per day. Our sample construction is illustrated in table 1 . There are 24,957 mothers and 22,174 fathers in our sample. 
Table 1. Sample Creation

Number of observations

85,452

Married and cohabiting individuals

84,988

Married and cohabiting individuals in heterosexual couples

67,646

Married and cohabiting individuals aged 25-64 in heterosexual couples

47,336

Only couples who have children in household under age 19

47,311

Drop those who slept more than $20 \mathrm{~h}$ on diary day

47,131

Drop those sick more than $4 \mathrm{~h}$ on diary day

Total sample size

Couples

Mothers

Fathers

22,174

Notes: Data from 2003-14 ATUS. See text for discussion of sample creation.

Our time use categories of interest are primary child caregiving, secondary child caregiving, solo time with children, and family time. Primary child caregiving includes all child-caregiving activities of providing direct care to children as a primary activity, e.g., providing direct physical care for children or reading to, playing with, and looking after children. ${ }^{10}$ Secondary child caregiving encompasses activities during which children are supervised, but not actively engaged by the respondent adult. In the ATUS, data on secondary child-caregiving activities are available only for the parents of children age 12 or younger. To avoid double counting, we exclude from our secondary child-caregiving time any time during which primary child caregiving was also provided, i.e., our categories of primary child caregiving and secondary child caregiving do not overlap.

We construct family time and solo time with children by aggregating detailed time use activities into the time spent together with spouse and/or child, using the "with whom" information from the ATUS data.

To explore whether the time use variables vary with state unemployment rates over the course of the 2003-14 business cycle, we use state-level unemployment rate data from the US Bureau of Labor Statistics (BLS). Following Aguiar, Hurst, and Karabarbounis (2013) and Morrill and

\footnotetext{
${ }^{10}$ We included codes 030101 to 040399 as primary child caregiving. This includes direct caregiving for children who live in the household and those who do not live in the household. The time devoted to nonhousehold children is quite low. See appendix table A for more information on codes used.
} 
Pabilonia (2015), we use an average of the 12 months ending in the interview month to control for variations in the state unemployment rate due to short-term sampling errors. For the 200314 period, the mean state yearly unemployment rate was 6.6 percent, the minimum rate was 2.6 percent, and the maximum rate was 14.0 percent. In our regression analysis, we control for long-term trends in time use and average unemployment rates, and use variations in unemployment rates within states over time to proxy state macroeconomic conditions (Aguiar, Hurst, and Karabarbounis 2013; Morrill and Pabilonia 2015).

We examine our models separately by race, ethnicity, and SES. For reasons discussed earlier, we expect the relationship between state unemployment rates and time use adjustments to be more pronounced in low-SES households, African-American households, and Hispanic households compared to their respective counterparts. By the end of 2014, mothers and fathers in our sample experienced job recovery and, with the exception of married African-American men, the unemployment rates were similar to their values in the last quarter of $2007 .{ }^{11}$ With additional data for the recovery in the years after 2010, we are able to explore the gendered patterns of time use over an expansion, a contraction, and another expansion that reflects job recovery for all demographic groups within our sample of mothers and fathers.

While we attempt to analyze the variations in care work that are correlated with macroeconomic conditions, our child-caregiving variables are imperfect. In particular, the "with whom" variable in the ATUS may overstate child-caregiving responsibilities given the possibility that many adults who may be sharing responsibility are present during an activity (Folbre and Yoon 2007). Also, as pointed out by Folbre and Yoon (2007), Connelly and Kimmel (2010), and others, the activities the ATUS defines as secondary child-caregiving activities may not reflect activities at all, i.e., it “does not designate an activity but rather a responsibility" (Connelly and Kimmel 2010: 36; see also Schwartz [2001]). These issues are further complicated by alternative conceptualizations of care work. For instance, Folbre (2006: 187) argues that indirect care (activities that support direct care such as preparing food for children, doing their laundry, etc.) is care work (see also Nelson

\footnotetext{
${ }^{11}$ Our calculations using BLS data show that in the last quarter of 2014, the unemployment rates among collegeeducated or non-college-educated women and men were 1 percentage point higher compared to their respective values in the last quarter of 2007. Similarly, among married women and men, the unemployment rates among Hispanics and whites were only half a percentage point higher compared to the last quarter of 2007. One exception is AfricanAmerican men, for whom the unemployment rate was 2.6 percentage points higher. However, this group also experienced job recovery after their unemployment rate peaked at 13.5 percent in the first quarter of 2011.
} 
[forthcoming]). However, despite the problems with categorizing secondary activities and the "with whom" question, Folbre and Yoon (2007) argue that it would be wrong to simply ignore secondary care responsibilities. Instead we take a broad-based approach and in doing so contribute to a more comprehensive and nuanced understanding of care work during the recession.

\section{EMPIRICAL MODEL AND RESULTS}

Similar to Morrill and Pabilonia (2015), we model the relationship between child-caregiving time and the state unemployment rate as follows:

Child-caregiving time ist $=\alpha+\beta_{1} *$ Urate $_{\mathrm{s}, \mathrm{t}-1}+\beta_{2} *$ Urate $^{2}-1 \mathrm{~s}, \mathrm{t}, \beta_{3} *$ Urate $_{, \mathrm{t}-1} \mathrm{~s} \gamma \mathrm{X}_{\mathrm{ist}}+\delta_{\mathrm{s}}+\theta_{\mathrm{t}}+\varepsilon_{\text {ist }}$

where Child-caregiving time ist $_{\text {is }}$ the minutes parent $i$ living in state $s$ at time $t$ spends engaged in childcare activities; Urate st $\mathrm{t}-1_{1}$ is the monthly state-level unemployment rate averaged over the prior 12 months ending in the interview month $(\mathrm{t}-1)$; $\mathrm{X}_{\text {ist }}$ is a vector of controls for individual and family characteristics; $\alpha$ is a constant; $\delta$ s are state fixed effects; $\theta$ s are year fixed effects; and $\varepsilon_{\text {ist }}$ is a stochastic disturbance term assumed to follow a normal distribution. ${ }^{12}$ We estimate all models of child-caregiving time using ordinary least squares. ${ }^{13}$ To examine whether the relationship between state macroeconomic conditions and our variables of interest vary by SES, we estimate equation 1 separately for low-SES and high-SES households, which we differentiate by whether the father in the household has a college degree. We also estimate equation 1 separately for African-American

\footnotetext{
${ }^{12}$ The individual and family-level control variables are as follows: own and spouse's age and age squared and indicators for the following: husband and wife's education (high-school dropout, some college, college, and missing, with high-school degree being the omitted category); race and ethnicity (non-Hispanic black, other, and Hispanic, with non- Hispanic white being the omitted category); gender; age of youngest household child (infant, preschooler, and elementary-school aged, with high-school aged being the omitted category); presence of household child older than age 18; number of children in the household by age group (ages $0-1,2-4,5-9,10-14$, and 15-18); cohabiting unmarried couple; gender composition of the children (all boy children and mixed gender children, with all girls being the omitted category); respondent lives in a standard metropolitan statistical area (SMSA); and season (with fall being the omitted category). For a review of the microeconomic literature that links most of these variables to time use, see Connelly and Kimmel (2010).

${ }^{13}$ We use ATUS final weights for nationally representative results and, following the methodology by Morrill and Pabilonia (2015), we reweight these weights to ensure equal day-of-week representation for each of our subsamples. In all regressions, we cluster standard errors by state of residence.
} 
mothers and fathers, white mothers and fathers, and Hispanic mothers and fathers.

\subsection{Primary Child-caregiving Time}

The results for primary child-caregiving time from the estimation of equation (1) for the full sample of mothers are presented in panel A and for fathers in panel B of table 2. We find a cubic relationship between mothers' primary child-caregiving time and the unemployment rate, where mothers spend the most time on primary child-caregiving activities when the unemployment rate is at its lowest and the least time when the unemployment rate is at its highest, with a slight increase in their primary child-caregiving time when the unemployment rate is between 6 percent and 8 percent. Any variation in mothers' primary childcare time is small in absolute terms until the unemployment rate exceeds 10 percent.

For fathers we find a quadratic (U-shaped) relationship between primary childcare time and the unemployment rate, where unemployment rates between 3 percent and 6 percent are associated with fewer minutes spent on primary child caregiving; when the unemployment rate exceeds 6 percent, fathers spend more time providing primary child caregiving. 
Table 2. Primary Child-caregiving Time (in Minutes), 2003-14

\begin{tabular}{|c|c|c|c|c|c|c|c|c|c|c|c|}
\hline & Sample & & $\mathrm{N}$ & $\begin{array}{l}\text { Mean primary } \\
\text { child care time }\end{array}$ & Urate & & Urate2 & & Urate3 & & $\mathrm{R}^{2}$ \\
\hline \multirow[t]{3}{*}{$\overline{(A)}$} & Mothers & Linear & 24,957 & 118 & -0.751 & $(1.055)$ & & & & & 0.244 \\
\hline & & Quadratic & 24,957 & 118 & 0.013 & $(3.927)$ & -0.046 & $(0.238)$ & & & 0.244 \\
\hline & & Cubic & 24,957 & 118 & $-18.506^{*}$ & $(9.727)$ & $2.482 * *$ & (1.199) & $-0.108 * *$ & $(0.049)$ & 0.244 \\
\hline \multirow[t]{3}{*}{ (B) } & Fathers & Linear & 22,174 & 59 & $2.154 *$ & $(1.220)$ & & & & & 0.121 \\
\hline & & Quadratic & 22,174 & 59 & $-5.129 *$ & $(2.853)$ & $0.427 * *$ & $(0.169)$ & & & 0.121 \\
\hline & & Cubic & 22,174 & 59 & -1.693 & $(6.854)$ & -0.039 & $(0.859)$ & 0.020 & $(0.037)$ & 0.121 \\
\hline \multicolumn{12}{|c|}{ Mothers, subsamples by SES and race-ethnicity (Estimates using cubic specification) } \\
\hline \multirow[t]{2}{*}{ (C) } & SES & Low-SES & 14,900 & 105 & $-29.508 *$ & $(16.889)$ & 3.932 & $(2.364)$ & -0.170 & $(0.109)$ & 0.204 \\
\hline & & High-SES & 10,057 & 140 & -1.863 & $(24.840)$ & 0.373 & $(3.579)$ & -0.017 & $(0.161)$ & 0.292 \\
\hline \multirow[t]{3}{*}{ (D) } & Race/ethnicity & White & 18,258 & 123 & -14.754 & (13.849) & 1.737 & $(1.803)$ & -0.069 & $(0.076)$ & 0.264 \\
\hline & & African-American & 1,338 & 89 & 16.712 & $(33.382)$ & -2.605 & $(4.633)$ & 0.147 & $(0.197)$ & 0.274 \\
\hline & & Hispanic & 3,678 & 108 & -49.360 & (31.338) & $7.510^{*}$ & $(4.062)$ & $-0.354 * *$ & $(0.174)$ & 0.187 \\
\hline \multicolumn{12}{|c|}{ Fathers, subsamples by SES and race-ethnicity (Estimates using quadratic specification) } \\
\hline \multirow[t]{2}{*}{ (E) } & SES & Low-SES & 12,881 & 52 & $-5.598 *$ & $(3.112)$ & $0.475 * * *$ & $(0.170)$ & & & 0.103 \\
\hline & & High-SES & 9,293 & 72 & -5.427 & $(5.884)$ & 0.424 & $(0.364)$ & & & 0.136 \\
\hline \multirow[t]{3}{*}{ (F) } & Race/ethnicity & White & 16,259 & 62 & -2.485 & $(3.259)$ & 0.244 & $(0.193)$ & & & 0.138 \\
\hline & & African-American & 1,379 & 51 & 3.191 & $(11.676)$ & -0.068 & $(0.610)$ & & & 0.151 \\
\hline & & Hispanic & 3,093 & 49 & $-13.468 *$ & $(6.722)$ & $0.906 * * *$ & $(0.332)$ & & & 0.111 \\
\hline
\end{tabular}

Notes: The sample includes women and men between the ages of 25 to 64 , who reside in the same household with their married or unmarried partner and at least one household child under age 19. The dependent variable is family time (any time with spouse/partner and at least one child). Urate is state-level unemployment rates averaged over the 12-month period prior to the survey, ending in the survey month. In alternative specifications we include linear, quadratic, and cubic polynomials in state-level unemployment rates. We control for state and year fixed effects, and the following individual and family-level variables: own and spouse's age and age squared and indicators for the following: husband and wife's education (high-school dropout, some college, college, and missing, with high-school degree being the omitted category); race and ethnicity (non-Hispanic black, other, and Hispanic, with non-Hispanic white being the omitted category); gender; age of youngest household child (infant, preschooler, and elementary-school aged, with high-school aged being the omitted category); presence of household child older than age 18; number of children in the household by age group (ages $0-1,2-4,5-9,10-14$, and 15-18); cohabiting unmarried couple; gender composition of the children (all boy children and mixed gender children, with all girls being the omitted category); respondent lives in SMSA; and season (with fall being the omitted category). We use ATUS weights and, following Morrill and Pabilonia (2015), we reweight these weights to ensure equal day-of-week representation for each of our subsamples. Standard errors adjusted for clustering by state are reported in parentheses. *** Significant at 1 percent; ** significant at 5 percent; $*$ significant at 10 percent. 
During the recession, the average unemployment rate in the US increased from 5 percent in December 2007 to 10 percent in June 2009. According to our estimates, mothers spent the same amount of time - 118 minutes per day - providing primary child caregiving when the unemployment rate was at 5 percent or 10 percent. Fathers, on the other hand, spent 57 minutes when the unemployment rate was at 5 percent, but seven more minutes (64 minutes in total) when it reached 10 percent. The seven-minute difference is equal to 12 percent of the sample mean of 59 minutes.

We also estimate equation 1 separately for subsamples of mothers and fathers, and present these results in panels $\mathrm{C}-\mathrm{F}$ in table 2. For mothers in low-SES households we find a cubic relationship between mothers' primary child-caregiving time and the unemployment rate. Compared to when it is at 5 percent, when the unemployment rate is at 10 percent mothers in low-SES households spend 1.6 fewer minutes engaged in primary child-caregiving activities (table 2, panel C). While the point estimates for mothers in high-SES households are not statistically significant, they show that mothers spend 3.4 more minutes on primary child-caregiving activities when the unemployment rate is at 10 percent compared to when it is at 5 percent. For fathers in low-SES and high-SES households, the point estimates are similar to the full sample results, but they are statistically significant only for fathers in low-SES households. Compared to when it is at 5 percent, when the unemployment rate is at 10 percent fathers in low-SES households spend about four more minutes on primary child-caregiving activities, and fathers in high-SES households spend about seven more minutes. However, the latter relationship is not statistically significant. These results suggest that if there is a substitution of fathers' care for mothers' care - in the face of an added-worker effect, for instance - this is more likely to occur in lowSES households compared to their counterparts. For high-SES households, our results are interpreted as either no effect on the primary child-caregiving time of fathers or mothers, or an increase in both.

In figure 1 we plot the estimated relationships between the state unemployment rate and the time mothers and fathers spend on primary child-caregiving activities. Figure 1 shows that at low unemployment rates mothers in the full sample spend more time on these activities compared to fathers. We also estimate this separately for low-SES and high-SES households and find that in high-SES households mothers spend considerably more time on primary child-caregiving 
activities than their counterparts in low-SES households. For instance, when the unemployment rate is at 3 percent, mothers in high-SES households spend about 18 more minutes on primary child-caregiving activities. The gap widens to about 32 minutes when the unemployment rate is at 5 percent and to about 37 minutes when the unemployment rate is at 10 percent. That the gap widens at higher unemployment rates suggests that the recession's impact on low-SES households goes beyond its effects in the productive sphere, possibly widening the care gap between low-SES and high-SES households.

Examining our results for subsamples differentiated by race and ethnicity we find a pronounced cubic relationship between primary child-caregiving time and the unemployment rate for Hispanic mothers (table 2, panel D). The point estimates for white mothers are smaller and not statistically significant, and the estimates for African-American mothers show an inverse pattern compared to white mothers and Hispanic mothers, but they are also not statistically significant. Hispanic mothers and white mothers spend the most time on primary child caregiving when the unemployment rate is at its lowest and the least time on these activities when the unemployment rate is at its highest; however, these relationships are statistically significant only for Hispanic mothers. The opposite relationship seems to hold for African-American mothers, but this is not statistically significant. Compared to when it is at 5 percent, when the unemployment rate is at 10 percent Hispanic mothers spend more time on primary child-caregiving activities, while white mothers and African-American mothers spend about the same amount of time engaged in these activities when the unemployment rate is at 5 or 10 percent. 


\section{Figure 1. Primary Child-caregiving Time of Mothers and Fathers by Socioeconomic Status}

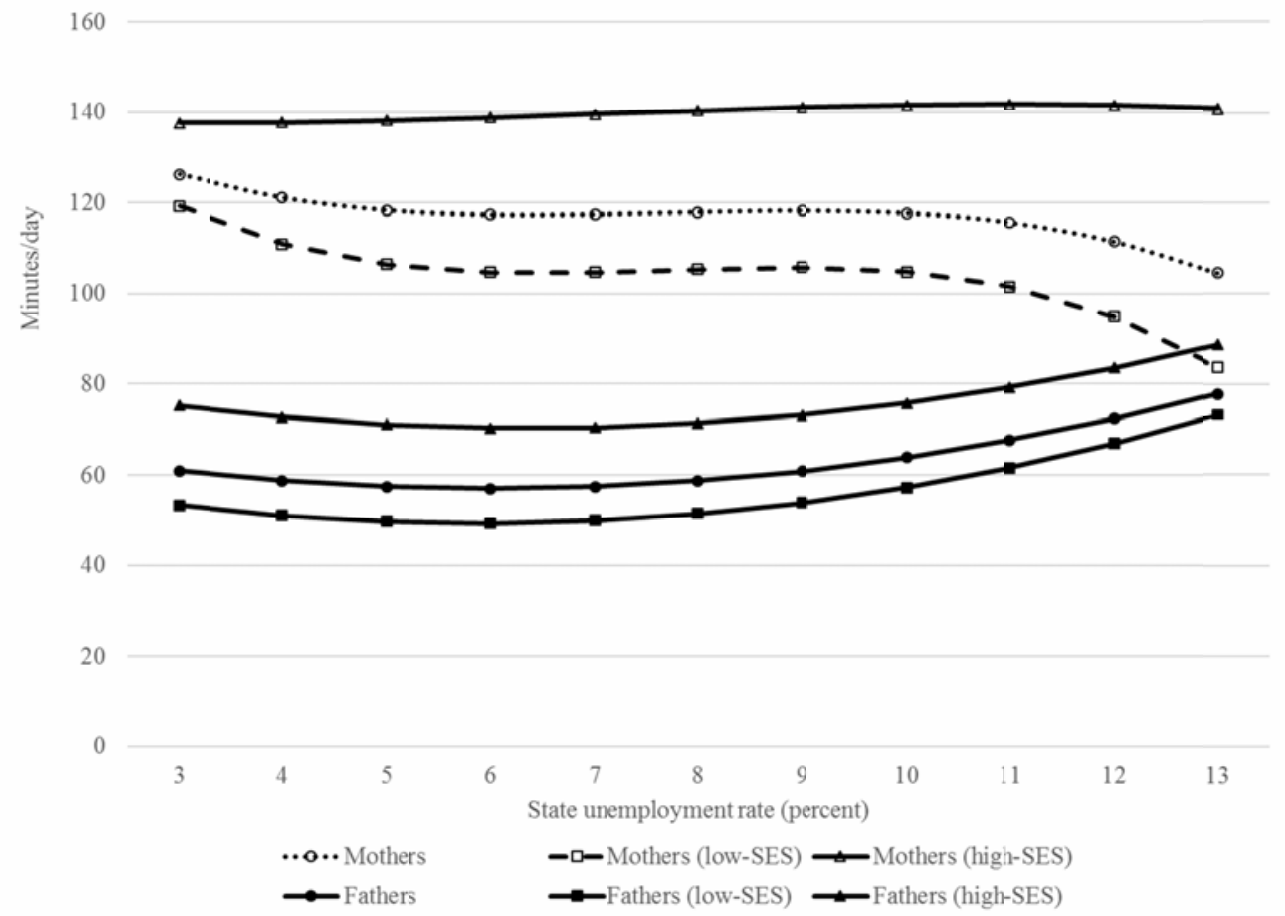

Notes: Authors' calculations from 2003-14 ATUS and US Bureau of Labor Statistics data. Figure 1 shows the predicted mean minutes spent on primary childcare activities (by estimating equation 1 in quadratic form) and matches quadratic specifications in table 2, panels $\mathrm{A}, \mathrm{B}, \mathrm{C}$, and $\mathrm{E}$. The state unemployment rate is averaged over the 12 months ending in the interview month. See text for details on sample construction and variable definitions.

For Hispanic fathers (table 2, panel F), point estimates are also statistically significant, and compared to our full sample results and the results for white fathers they are also larger.

Hispanic fathers' primary child-caregiving time varies by less than a minute between the unemployment rates of 5 and 10 percent, increasing when the unemployment rates exceed 10 percent. While not statistically significant, primary child-caregiving time in African-American households seems to follow a different pattern compared to their white and Hispanic counterparts, indicating different patterns of household adjustment in African-American households. We present these relationships in figure 2. At low unemployment rates, Hispanic mothers spend more time on primary child-caregiving activities, followed by white mothers and African-American mothers. These differences likely reflect the fact that married African-American mothers have the highest labor force participation rates and married Hispanic married mothers have the lowest, 
with married white mothers in the middle. ${ }^{14}$ Compared to when the unemployment rates are very low, when the unemployment rates are very high the differences in the time mothers spend on primary child-caregiving activities by race and ethnicity are smaller. This is because Hispanic mothers and white mothers spend less time and African-American mothers spend more time on these activities at high unemployment rates - with the latter possibly due to loss of employment among African-American mothers who are more likely to participate in the labor force than their counterparts, and for whom the unemployment rate increased more during the recession.

In sum, the results for fathers' primary child caregiving are consistent with the previous findings in the literature: fathers spend more time on primary child-caregiving activities in a recessionary context (Casper and O'Connell 1998; Berik and Kongar 2013). Similarly, our results for mothers are consistent with the findings in the literature: mothers' primary child-caregiving time is not much affected by the recession (Berik and Kongar 2013). However, our new analysis also suggests that worsening state macroeconomic conditions are associated with different patterns of mothers' primary child-caregiving time in low-SES households compared to high-SES households, where mothers in low-SES households spend less time on primary child-caregiving activities when the unemployment rate is at 10 percent compared to when it is at 5 percent. We do not observe a decline in mothers' primary caregiving time in high-SES households, leading to a widening SES gap for mothers’ primary child-caregiving time.

\footnotetext{
${ }^{14}$ In 2012, among married mothers (spouse present), the labor force participation rate was 75.3 percent for AfricanAmericans, 68.5 percent for whites, and 58.9 percent for Hispanics (BLS 2014: 20; table 6).
} 


\section{Figure 2. Primary Childcare Time of Mothers and Fathers by Race and Ethnicity}

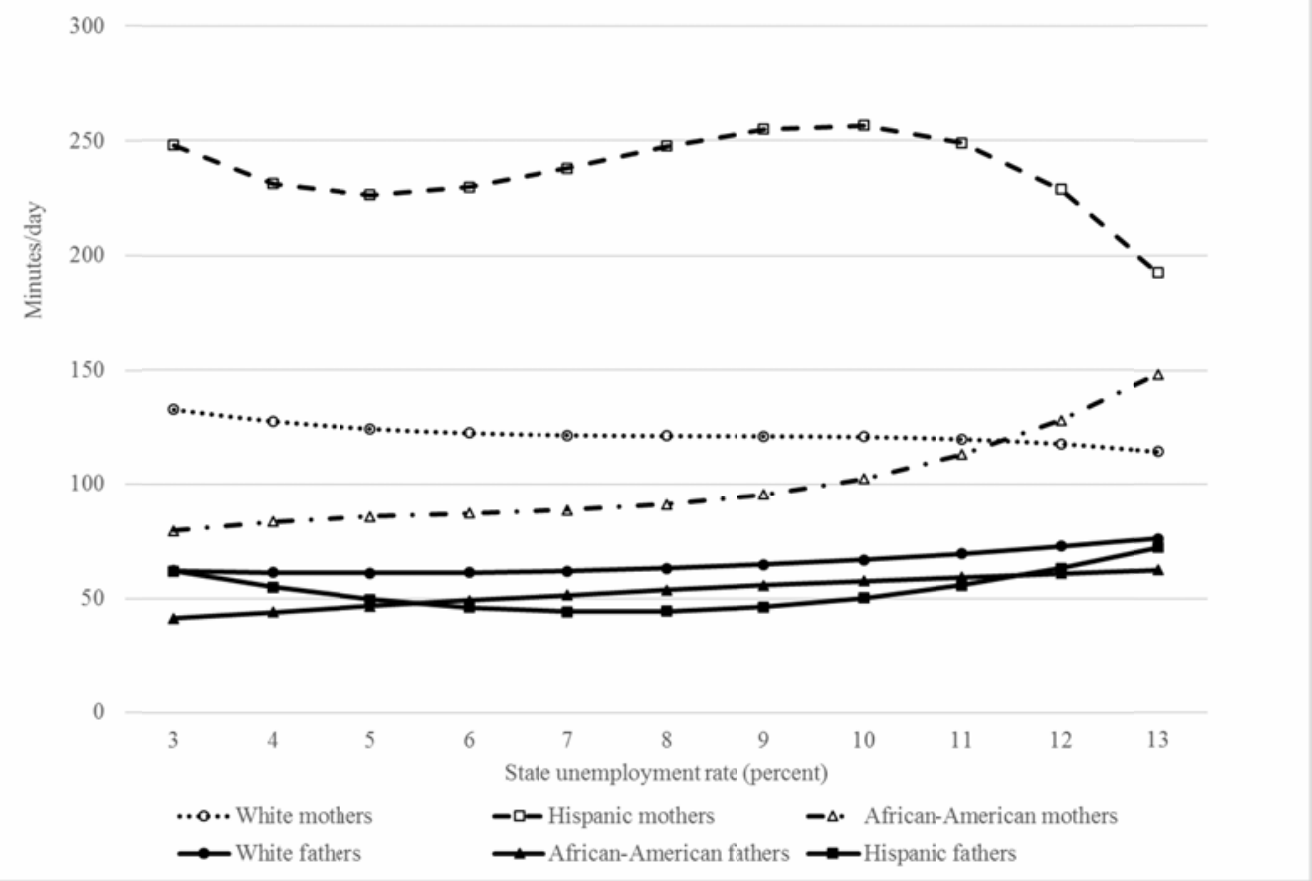

Notes: See notes to figure 1. Figure 2 matches the specification in table 2, panels D and F.

Moreover, if there is an added-worker effect during the recession and a subsequent substitution of fathers' care for mothers', this is more likely to be the case in low-SES households; we present more evidence of the added-worker effect below. In terms of gender differences in primary child-caregiving time, our results suggest that the gap is narrower at higher unemployment rates (as fathers provide more primary child caregiving possibly due to disproportionate job losses for men). The differences by race and ethnicity are also smaller at very high unemployment rates, indicating different adjustments in time use across households when state macroeconomic conditions worsen.

\subsection{Secondary Child-caregiving Time}

We explore whether secondary child-caregiving time varies with macroeconomic conditions by estimating equation 1 with time spent on secondary child-caregiving activities as the dependent variable. Our secondary child-caregiving variable is the time spent on secondary child-caregiving activities for children under the age 13 and excludes any secondary child-caregiving time during which primary care was also provided. It is possible that secondary child-caregiving time varies more with macroeconomic conditions than primary child-caregiving time (as predicted by the 
microeconomic literature), but this does not appear to be the case. The results presented in table 3 show a U-shaped relationship between mothers' secondary child-caregiving time and the unemployment rate, where the time mothers spend on secondary child-caregiving activities declines until the unemployment rate reaches 7 percent and increases afterwards (panel A). When the unemployment rate is at 10 percent, mothers spend about 1.5 more minutes on secondary child-caregiving activities compared to when the unemployment rate is at 5 percent. Panel B in table 3 shows that fathers' secondary child-caregiving time also follows a U-shaped pattern, but the coefficients are not statistically significant.

When we restrict our samples to low-SES households, we find a more pronounced and statistically significant U-shaped relationship for both mothers and fathers (table 3, panels C and $\mathrm{E})$. 
Table 3. Secondary Child-caregiving Time (in Minutes), 2003-14

\begin{tabular}{|c|c|c|c|c|c|c|c|c|c|}
\hline & Sample & & $\mathbf{N}$ & Mean & Urate & & Urate2 & & $\mathbf{R}^{2}$ \\
\hline$(\mathrm{A})$ & Mothers & Quadratic Urate & 24,957 & 317 & $-17.393 * *$ & $(7.344)$ & $1.181 * * *$ & $(0.426)$ & 0.251 \\
\hline (B) & Fathers & Quadratic Urate & 22,174 & 214 & -7.446 & $(4.901)$ & 0.409 & $(0.278)$ & 0.127 \\
\hline \multicolumn{10}{|c|}{ Mothers, subsamples by SES and race-ethnicity (Estimates using quadratic specification) } \\
\hline$(\mathrm{C})$ & SES & Low-SES & 14,900 & 318 & $-28.201 * * *$ & $(9.937)$ & $1.979 * * *$ & $(0.570)$ & 0.248 \\
\hline \multirow{4}{*}{ (D) } & \multirow{4}{*}{ Race/ethnicity } & High-SES & 10,057 & 314 & 5.392 & $(11.494)$ & -0.420 & $(0.703)$ & 0.267 \\
\hline & & White & 18,258 & 305 & $-16.799 *$ & $(8.629)$ & $0.968^{*}$ & $(0.493)$ & 0.266 \\
\hline & & African-American & 1,338 & 280 & -18.543 & $(24.710)$ & 1.491 & $(1.413)$ & 0.234 \\
\hline & & Hispanic & 3,678 & 372 & -9.032 & $(24.785)$ & 1.015 & $(1.275)$ & 0.247 \\
\hline \multicolumn{10}{|c|}{ Fathers, subsamples by SES and race-ethnicity (Estimates using quadratic specification) } \\
\hline \multirow[t]{2}{*}{$(\mathrm{E})$} & SES & Low-SES & 12,881 & 212 & $-17.818^{* *}$ & $(7.710)$ & $1.031 * *$ & $(0.427)$ & 0.130 \\
\hline & & High-SES & 9,293 & 218 & 6.661 & (11.175) & -0.497 & $(0.534)$ & 0.133 \\
\hline \multirow[t]{3}{*}{$(\mathrm{F})$} & Race/ethnicity & White & 16,259 & 211 & $-14.358^{* *}$ & $(5.804)$ & $0.910 * * *$ & $(0.326)$ & 0.145 \\
\hline & & African-American & 1,379 & 222 & -47.984 & $(32.592)$ & 1.904 & $(1.959)$ & 0.179 \\
\hline & & Hispanic & 3,093 & 217 & 14.019 & $(18.764)$ & -0.707 & $(1.107)$ & 0.109 \\
\hline
\end{tabular}

Notes: See notes to table 1. 
Compared to when the unemployment rate is at 5 percent, mothers in low-SES households spend about 7.5 more minutes on secondary child-caregiving activities and fathers in these households spend 12 fewer minutes on these activities when the unemployment rate is at 10 percent. When the unemployment rate rises above 10 percent, both mothers and fathers in low-SES households spend more time providing secondary child caregiving. For high-SES households, the estimates have the opposite signs and are not statistically significant. Our results suggest a U-shaped relationship between the unemployment rate and the secondary child-caregiving time of mothers and fathers, which reflects the results in low-SES households.

To illustrate the differences in the relationship between the unemployment rate and secondary child-caregiving time, in figure 3 we plot the relationships between the unemployment rate and secondary child-caregiving time of mothers and fathers for the full sample and also separately for mothers and fathers in low-SES households. Compared to the primary child-caregiving time reported earlier, there is less of a difference in time spent on secondary child-caregiving activities between low-SES and high-SES households until the unemployment rate exceeds 10 percent; however, similar to primary child-caregiving time, macroeconomic conditions affect secondary child-caregiving time more in low-SES households. We also find that the gender gap in secondary child-caregiving time is substantial, with mothers spending considerably more time on these activities. Compared to when the unemployment rate is lower than 5 percent, these differences are smaller when the unemployment rate is between 5-8 percent, and larger at very high unemployment rates.

Panel D in table 3 shows that when the sample is restricted by the race and ethnicity of the mothers in our sample, we observe the same U-shaped pattern for all groups of mothers, but the relationship is statistically significant only for white mothers. For African-American fathers and white fathers, we also find a U-shaped relationship (panel F). While the point estimates are larger for African-American fathers, they are not statistically significant. The point estimates for Hispanic fathers indicate a reverse pattern compared to African-American fathers and white fathers, but they are statistically insignificant. 


\section{Figure 3. Secondary Child-caregiving Time by Socioeconomic Status (in Minutes)}

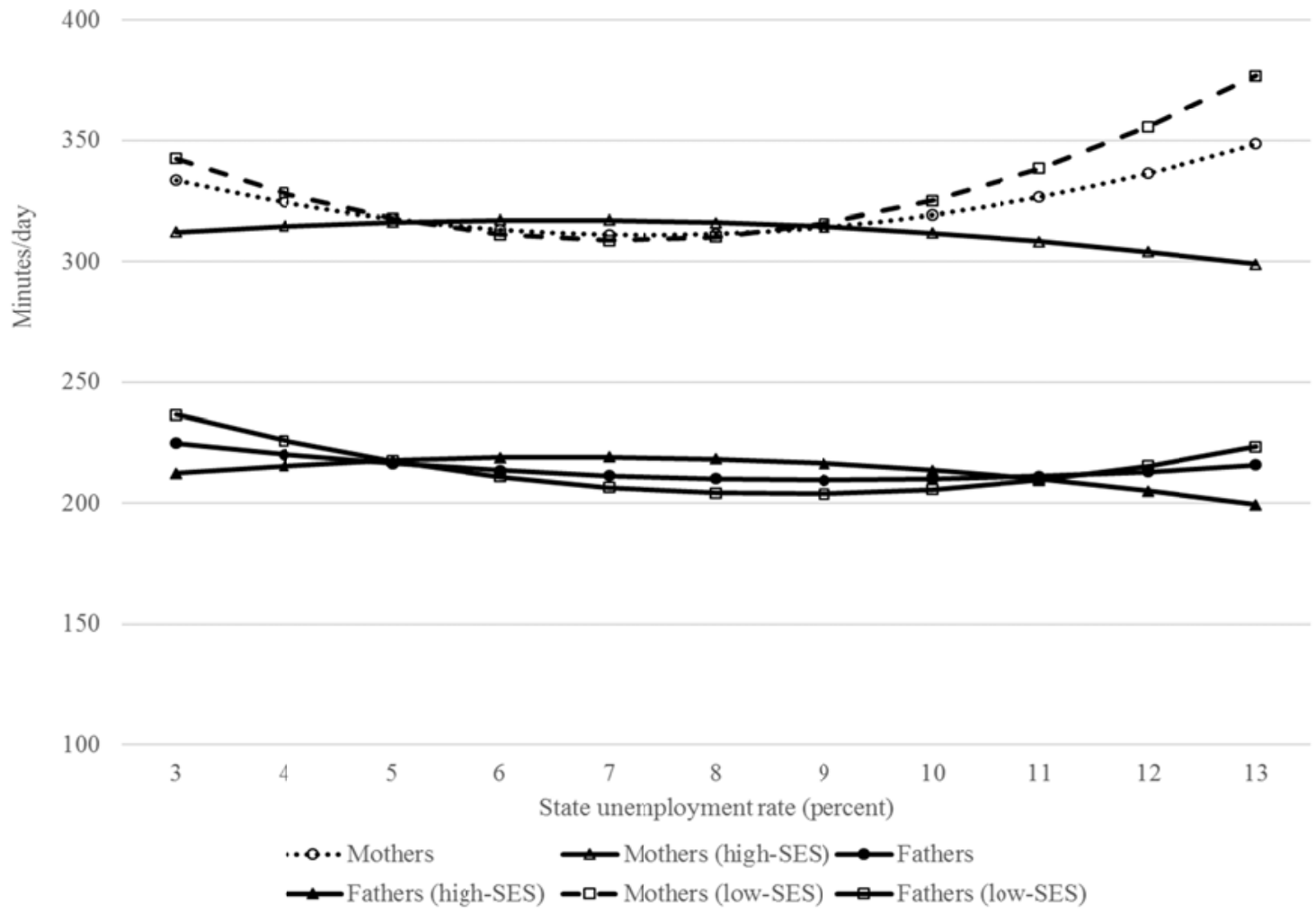

Notes: See notes to figure 1 . Figure 3 shows the predicted mean minutes spent on secondary childcare activities with 95 percent confidence intervals and matches quadratic specifications in table 3, panels A, B, C, and E.

\subsection{Solo Time with Children}

The next child-caregiving activity we examine is solo time spent with children under age 19. We estimate equation 1 with the dependent variable solo time with children separately for mothers and fathers. Our findings are reported in table 4. For fathers, there is a cubic relationship between the state unemployment rate and the time they spend solo with children, where fathers' solo time with children is at its highest at the lowest unemployment rates and is at its lowest at the highest unemployment rates (panel B). The cubic relationship between the unemployment rate and fathers' solo time with children is mirrored by the results for mothers in the full sample, i.e., the patterns for mother and fathers appear to be complementary; however, for mothers our estimates are not statistically significant (panel A). 
Table 4. Mothers' and Fathers' Solo Time with Children under Age 19 (in Minutes), 2003-14

\begin{tabular}{|c|c|c|c|c|c|c|c|c|c|c|c|c|}
\hline$\overline{(\mathrm{A})}$ & Full sample & Mothers & Linear & $\mathbf{N}$ & Mean & Urate & & Urate2 & & Urate3 & & $\mathbf{R 2}$ \\
\hline \multirow{5}{*}{ (B) } & & & Quadratic & 24,957 & 219 & 5.022 & $(6.429)$ & -0.288 & $(0.348)$ & & & 0.161 \\
\hline & & & Cubic & 24,957 & 219 & -7.699 & $(20.360)$ & 1.448 & $(2.723)$ & -0.074 & $(0.115)$ & 0.161 \\
\hline & & Fathers & Linear & 22,174 & 87 & 0.680 & $(1.355)$ & & & & & 0.048 \\
\hline & & & Quadratic & 22,174 & 87 & -5.900 & $(4.230)$ & 0.386 & $(0.237)$ & & & 0.048 \\
\hline & & & Cubic & 22,174 & 87 & 14.629 & (12.934) & -2.398 & (1.649) & $0.118^{*}$ & $(0.069)$ & 0.049 \\
\hline \multicolumn{13}{|c|}{ Estimates using quadratic specification and various subsamples } \\
\hline \multirow[t]{2}{*}{$(\mathrm{C})$} & SES & Mothers & Low-SES & 14,900 & 214 & 3.687 & $(7.679)$ & -0.241 & $(0.403)$ & & 0.156 & \\
\hline & & & High-SES & 10,057 & 226 & 6.230 & $(9.120)$ & -0.328 & $(0.544)$ & & 0.182 & \\
\hline \multirow[t]{2}{*}{ (D) } & & Fathers & Low-SES & 12,881 & 84 & -9.468 & $(8.632)$ & 0.596 & $(0.499)$ & & 0.051 & \\
\hline & & & High-SES & 9,293 & 92 & -0.273 & $(6.719)$ & 0.092 & $(0.399)$ & & 0.055 & \\
\hline \multirow{3}{*}{ (E) } & Race/ethnicity & Mothers & White & 18,258 & 217 & 5.223 & $(6.517)$ & -0.357 & $(0.395)$ & & 0.180 & \\
\hline & & & African-American & 1,338 & 185 & -1.985 & $(20.414)$ & 0.502 & $(1.387)$ & & 0.208 & \\
\hline & & & Hispanics & 3,678 & 237 & 19.246 & $(26.280)$ & -1.072 & $(1.272)$ & & 0.147 & \\
\hline \multirow[t]{3}{*}{$(\mathrm{F})$} & & Fathers & White & 16,259 & 90 & -2.558 & $(4.498)$ & 0.238 & $(0.253)$ & & 0.055 & \\
\hline & & & African-American & 1,379 & 95 & $-45.075 * *$ & $(17.180)$ & $1.869 * *$ & $(0.906)$ & & 0.105 & \\
\hline & & & Hispanic & 3,093 & 74 & 3.707 & (11.309) & -0.066 & $(0.715)$ & & 0.053 & \\
\hline \multicolumn{13}{|c|}{ Estimates using cubic specification and various subsamples } \\
\hline \multirow[t]{2}{*}{$(\mathrm{G})$} & SES & Mothers & No college & 14,900 & 214 & -15.563 & $(28.055)$ & 2.381 & $(3.844)$ & -0.112 & $(0.164)$ & 0.156 \\
\hline & & & College & 10,057 & 226 & 6.837 & $(28.614)$ & -0.411 & $(3.971)$ & 0.004 & $(0.178)$ & 0.182 \\
\hline \multirow[t]{2}{*}{$(\mathrm{H})$} & & Fathers & No college & 12,881 & 84 & 22.733 & $(18.258)$ & -3.751 & $(2.386)$ & $0.183^{*}$ & $(0.104)$ & 0.052 \\
\hline & & & College & 9,293 & 92 & 1.714 & $(13.614)$ & -0.180 & (1.819) & 0.012 & $(0.081)$ & 0.055 \\
\hline \multirow[t]{3}{*}{ (I) } & Race/ethnicity & Mothers & White & 18,258 & 217 & 5.878 & $(21.972)$ & -0.446 & $(3.128)$ & 0.004 & $(0.140)$ & 0.180 \\
\hline & & & African-American & 1,338 & 185 & -9.434 & $(78.177)$ & 1.535 & $(10.661)$ & -0.045 & $(0.462)$ & 0.208 \\
\hline & & & Hispanic & 3,678 & 237 & $-85.615^{*}$ & $(49.456)$ & $12.934 * *$ & $(5.923)$ & $-0.585^{* *}$ & $(0.240)$ & 0.148 \\
\hline \multirow[t]{3}{*}{$(\mathrm{J})$} & & Fathers & White & 16,259 & 90 & 5.563 & $(12.758)$ & -0.869 & $(1.612)$ & 0.047 & $(0.068)$ & 0.055 \\
\hline & & & African-American & 1,379 & 95 & -78.711 & $(51.628)$ & 6.393 & $(6.548)$ & -0.189 & $(0.266)$ & 0.107 \\
\hline & & & Hispanic & 3,093 & 74 & $126.838 * *$ & $(60.104)$ & $-16.608 * *$ & $(8.032)$ & $0.695^{*}$ & $(0.352)$ & 0.056 \\
\hline
\end{tabular}


We observe a cubic relationship for all subsamples of fathers, except for African-American fathers (panels $\mathrm{H}$ and $\mathrm{J}$ ). The cubic relationships are statistically significant only for fathers in low-SES households and also for Hispanic fathers. For African-American fathers, we find a quadratic relationship between solo time with children and the unemployment rate. The results for mothers in low-SES households, African-American mothers, and Hispanic mothers (panels G and I) mirror the results for fathers in low-SES households, African-American fathers, and Hispanic fathers, respectively, but the estimates are statistically significant only for Hispanic mothers.

We plot the relationships between solo time with children and the unemployment rate for our subsamples in figure 4. The estimates show complementary patterns for mothers and fathers, although only those for Hispanic mothers and Hispanic fathers are statistically significant. When the unemployment rate is 10 percent, compared to when the unemployment rate is 5 percent, Hispanic mothers spend about 19 more minutes alone with children, while Hispanic fathers spend about 10 fewer minutes. While not statistically significant, our results also show complementary patterns in African-American households, where African-American mothers spend more solo time with children at higher unemployment rates, while African-American fathers spend less time. Solo time spent with children seems to vary less with macroeconomic conditions in white households compared to African-American and Hispanic households. These results suggest a different pattern of time reallocation in subsamples differentiated by SES, race, and ethnicity. That the patterns for mothers and fathers in each of the subsamples appear to be complementary suggests that as macroeconomic conditions change, couples are coordinating their schedules so that one parent is with the children at a given point in time. Compared to their respective counterparts, this applies less to white and high-SES households, where the variations are small and statistically insignificant. 


\section{Figure 4. Solo Time with Children}

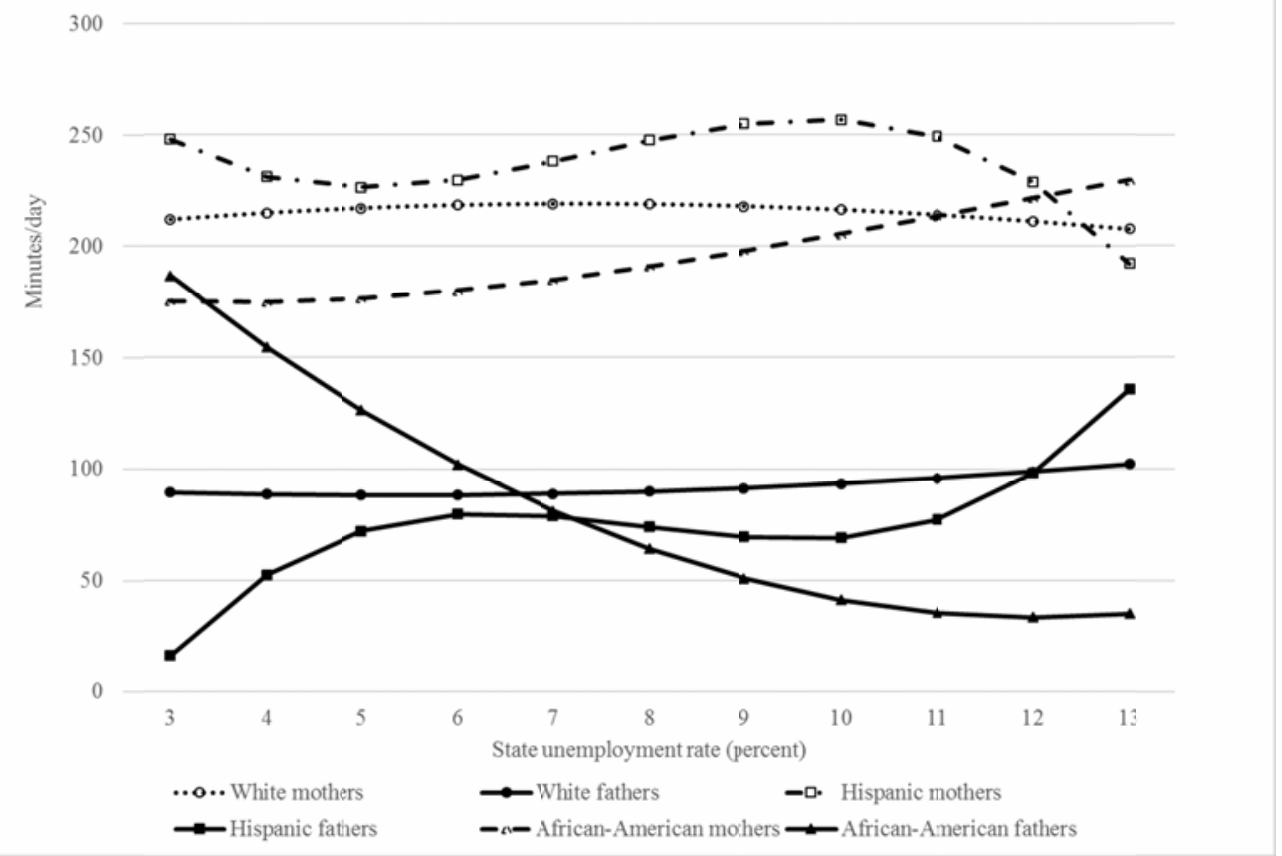

Notes: See notes to figure 1. Figure 4 shows the predicted mean minutes spent solo with children with 95 percent confidence intervals and matches quadratic specifications in table 4, Panels E, F, I, and J.

\subsection{Family Time}

The final child-caregiving variable of interest over the 2003-14 period is family time.

For a pooled sample of mothers and fathers, we estimate equation 1 with family time as the dependent variable. We present our results in table 5. Over the 2003-14 period, we find a quadratic (U-shaped) relationship between family time and the unemployment rate, i.e., families spend more time together when the state unemployment rate is low compared to when it is high, but at very high unemployment rates families begin to spend more time together. These findings are consistent with Morrill and Pabilonia (2015), who found that the time couples spend together followed a U-shaped pattern over the 2003-10 period, regardless of whether they are with or without their children during this time. Panel B shows our results for subsamples by socioeconomic status. We do not find a statistically significant relationship between family time and the unemployment rate for high-SES households, and point estimates are small, while the results for low-SES households are statistically significant and point estimates are larger than the full sample results. These findings suggest that the U-shaped relationship between family time and state unemployment rates primarily reflects the patterns of time use in low-SES households. 
Our estimates, however, show that in absolute terms the differences in the variation in family time between the unemployment rates of 5 to 10 percent is relatively small: when the unemployment rate is at 10 percent compared to when the unemployment rate is at 5 percent, family time is, on average, 5 minutes shorter in low-SES households and 3 minutes shorter in high-SES households. Figure 5 plots the relationships between the unemployment rate and family time for the full sample, as well as separately for low-SES and high-SES households, with the latter two not statistically significant.

Panel $\mathrm{C}$ in table 5 presents the results for our subsamples as differentiated by race and ethnicity. The results for white households are similar to the full sample results, but they are not statistically significant. The point estimates are larger and statistically significant for AfricanAmerican households. While the point estimates for Hispanic households are similar to the estimates for African-American households, they are not statistically significant. We find that with an increase in the unemployment rate from 5 to 10 percent, family time increases by more than 16 minutes in African-American households. In Hispanic households, our findings suggest a large (21 minute) decline in family time with an increase in the unemployment rate from 5 to 10 percent, but the estimates are not statistically significant. We plot these relationships in figure 6, noting that only the estimates for African-American households are statistically significant. 
Table 5. Family Time (in Minutes), 2003-14

\begin{tabular}{|c|c|c|c|c|c|c|c|c|c|}
\hline \multicolumn{3}{|c|}{ Sample } & $\mathbf{N}$ & Mean & Urate & & Urate2 & & $\mathbf{R 2}$ \\
\hline \multirow[t]{2}{*}{ (A) } & Full sample & Linear & 47,131 & 161 & -0.074 & $(1.453)$ & & & 0.048 \\
\hline & & Quadratic & 47,131 & 161 & -6.789 & $(4.071)$ & $0.398 * *$ & $(0.195)$ & 0.048 \\
\hline \multicolumn{10}{|c|}{ Estimates using quadratic specification and various subsamples } \\
\hline \multirow[t]{2}{*}{ (B) } & SES & No college & 27,781 & 157 & $-9.446^{*}$ & $(4.742)$ & $0.567 * *$ & $(0.228)$ & 0.051 \\
\hline & & Colle & 19,350 & 121 & -2.581 & (5.187) & 0.128 & $(0$. & 0.049 \\
\hline \multirow[t]{3}{*}{ (C) } & Race/ethnicity & White & 34,517 & 191 & -4.870 & (5.130) & 0.342 & $(0.277)$ & 0.042 \\
\hline & & African- & 2,717 & 171 & -18.273 & (15.703) & $1.393 *$ & $(0.789)$ & 0.055 \\
\hline & & Hispanic & 6,771 & 163 & -15.896 & (9.986) & 0.773 & $(0.484)$ & 0.058 \\
\hline
\end{tabular}

Notes: See notes to table 1.

Figure 5. Family Time by Socioeconomic Status

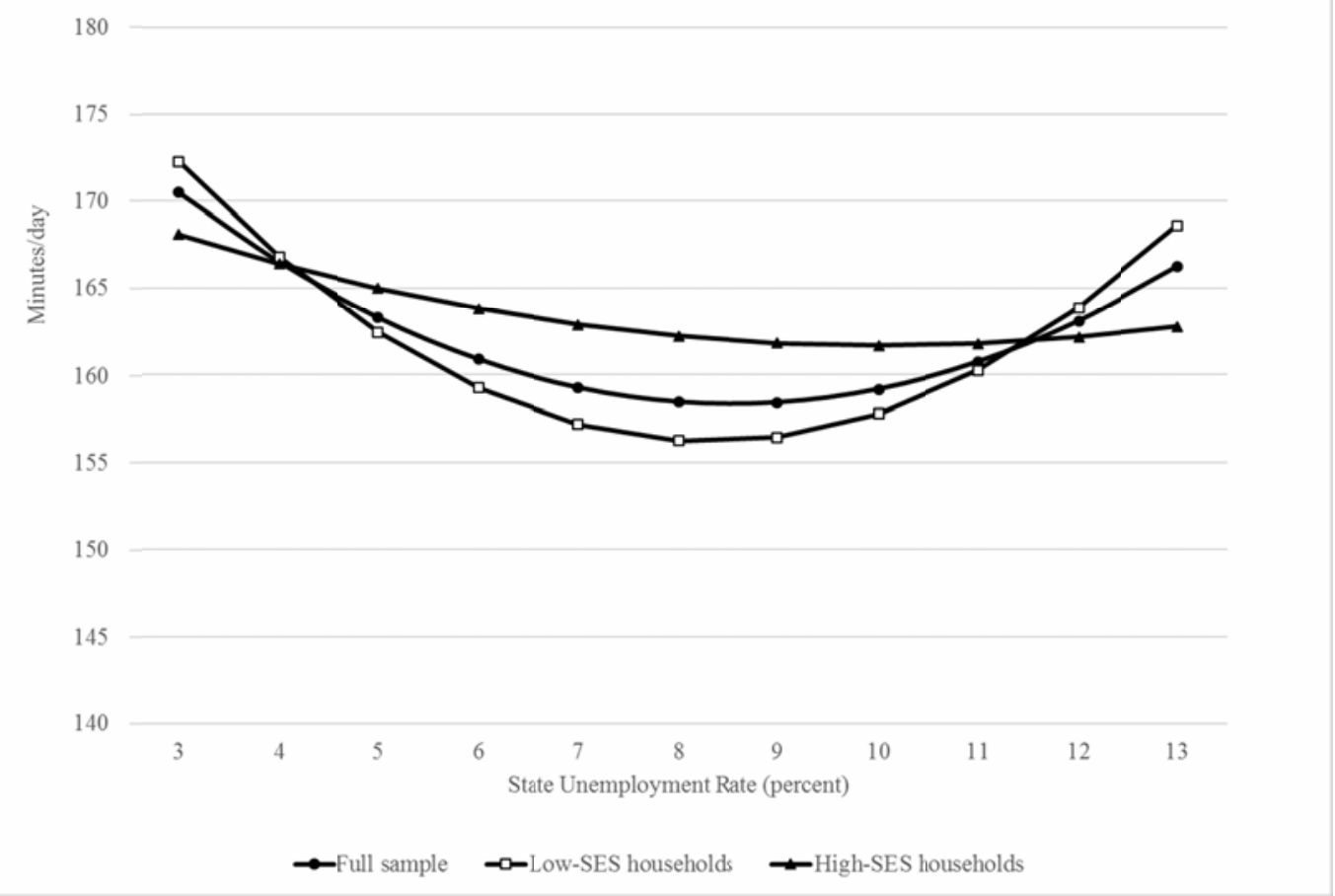

Notes: See notes to figure 1 . Figure 5 shows the predicted mean minutes spent as a family with 95 percent confidence intervals and matches quadratic specifications in table 5, panels A and B. 


\section{Figure 6. Family Time by Race and Ethnicity}

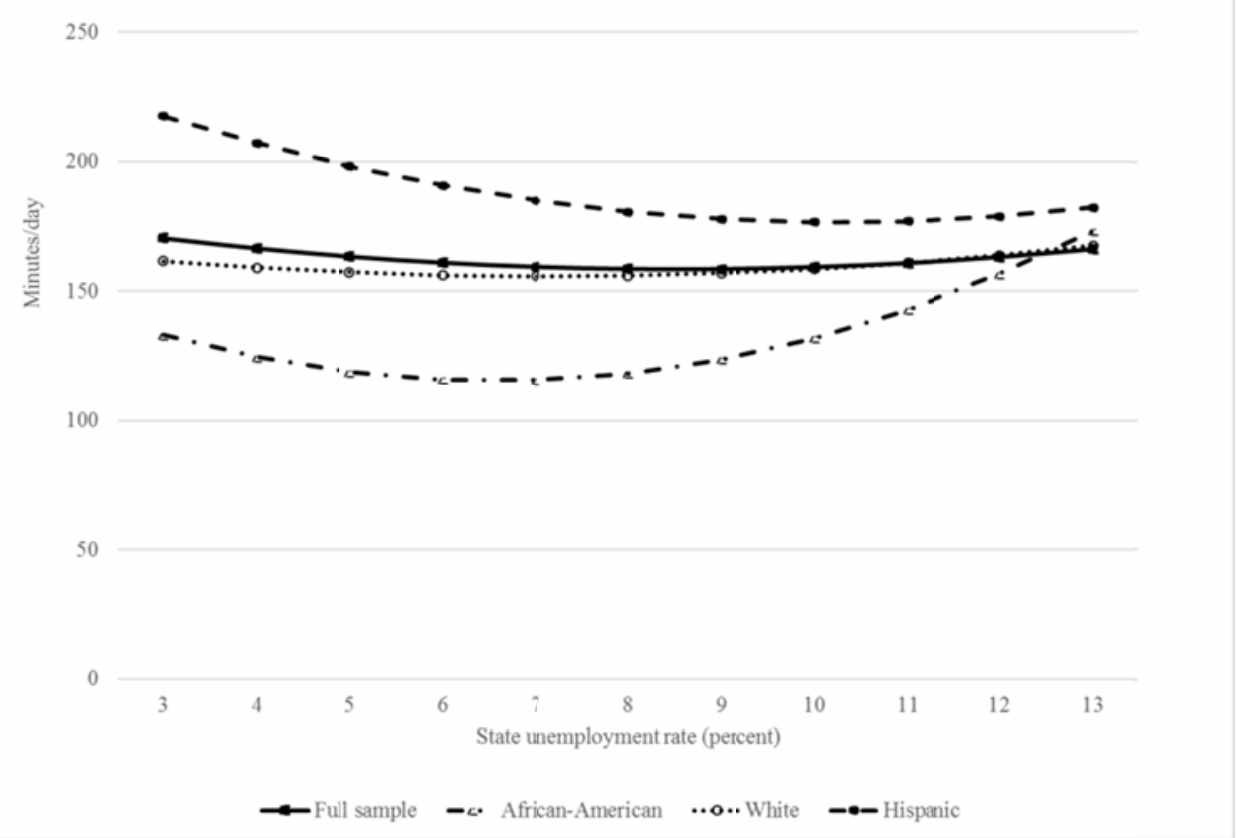

Notes: See notes to figure 1. Figure 6 shows the predicted mean minutes spent as a family with 95 percent confidence intervals and matches quadratic specifications in table 5, panels A and C.

\subsection{Paid Work and Work Schedules}

Morrill and Pabilonia (2015) find that couples spend less time together when the unemployment rate is at 10 percent compared to when it is at 5 percent, but couples spend more time together when the unemployment rate exceeds 9 percent. To explain the decline in the time couples spend together until the unemployment rate reaches 10 percent, Morrill and Pabilonia (2015) explore the possibility that couples are finding it difficult to coordinate their work schedules at high unemployment rates (between 8 to 10 percent). In this section, we examine the changes in time spent on paid work activities as well as the timing of work for the full sample - and also separately for subsamples differentiated by race and ethnicity, as well as by socioeconomic status - to explore the possibility of such adjustments by the mothers and fathers in our sample. Paid work time includes any time spent working at a primary job, as well as at other jobs and on work-related activities. Following Morrill and Pabilonia (2015), for mothers, fathers, and each subsample we estimate a separate Tobit model where the dependent variable is minutes worked for pay during the specified time period. In alternative specifications, we model the relationship between paid work time and state unemployment rates as linear, polynomial, and cubic. We present our results in tables 6 and 7, where the results for any time spent on paid work regardless 
of timing of work are presented in columns 1-3. Columns 4-6 present paid work during standard hours (weekdays between 8 am and $6 \mathrm{pm}$ ) and columns 7-12 present the time spent on paid work during nonstandard hours, with columns 7-9 showing the results for time spent on paid work on weekdays between $8 \mathrm{pm}$ and $6 \mathrm{am}$, and columns 10-12 showing the results for paid work time on weekends. In table 6, panels A and B present the results for mothers and fathers, respectively, and panels C-F present the results for mothers in low-SES households, mothers in high-SES households, fathers in low-SES households, and fathers in high-SES households. In table 7, we present the results for African-American, Hispanic, and white mothers and fathers.

The full sample results presented in table 6 show no statistically significant relationship between paid work time and state unemployment rates for mothers or for fathers (panels A and B, columns 1-3). ${ }^{15}$ However, when we limit the paid work hours to time spent on paid work activities during standard hours on weekdays, we find that fathers' paid work time declines linearly with an increase in the unemployment rate. For mothers, we do not find a statistically significant relationship between the unemployment rate and paid work time during any specified time period.

When we limit the sample to low-SES households, for mothers we find that paid work time on weekends declines linearly with an increase in the unemployment rate (column 10, panel C). For mothers in high-SES households, we do not find a statistically significant relationship between the unemployment rate and paid work hours during any specified time period. If there is a relationship, it is the inverse of that for mothers in low-SES households, i.e., in the linear specification, the coefficient estimate is positive, suggesting an increase in paid work hours, but this is not statistically significant (column 10, panel D). For fathers in low-SES households, total paid work time declines linearly with an increase in the unemployment rate (panel E, column 1). This is primarily due to fewer minutes of paid work during standard hours on weekdays. For these fathers, we also find a statistically significant nonlinear relationship between the unemployment rate and paid work time during nonstandard hours on weekdays, where fathers' paid work time during nonstandard hours on weekdays is at its lowest at the lowest unemployment rates and at its highest at the highest unemployment rates. We do not find a statistically significant relationship between the unemployment rate

\footnotetext{
${ }^{15}$ Morrill and Pabilonia (2015), who estimate these relationships using data for the 2003-10 period, also report estimates that are not statistically significant.
} 
and the paid work time of fathers in high-SES households. We present these relationships in figure 7. 
Table 6. Time Spent in Paid Work and Timing of Paid Work by Socioeconomic Status (in minutes)

\begin{tabular}{|c|c|c|c|c|c|c|c|c|c|c|c|c|}
\hline & \multicolumn{3}{|c|}{ All days } & \multicolumn{3}{|c|}{ Weekdays, 8 am to 6 pm } & \multicolumn{3}{|c|}{ Weekdays, 6 pm to 8 am } & \multicolumn{3}{|c|}{ Weekends } \\
\hline & (1) & (2) & (3) & (4) & (5) & (6) & (7) & (8) & (9) & (10) & (11) & (12) \\
\hline \multicolumn{13}{|c|}{ A: Mothers } \\
\hline Linear & $\begin{array}{l}-4.206 \\
(3.967)\end{array}$ & $\begin{array}{l}5.937 \\
(17.510)\end{array}$ & $\begin{array}{c}3.351 \\
(51.570)\end{array}$ & $\begin{array}{l}-2.833 \\
(3.940)\end{array}$ & $\begin{array}{c}2.432 \\
(16.561)\end{array}$ & $\begin{array}{c}42.210 \\
(48.808)\end{array}$ & $\begin{array}{c}0.602 \\
(1.840)\end{array}$ & $\begin{array}{c}9.383 \\
(8.089)\end{array}$ & $\begin{array}{l}7.526 \\
(26.145)\end{array}$ & $\begin{array}{c}-4.594 \\
(7.154)\end{array}$ & $\begin{array}{c}-0.763 \\
(37.494)\end{array}$ & $\begin{array}{l}-35.289 \\
(98.935)\end{array}$ \\
\hline \multicolumn{13}{|c|}{ B: Fathers } \\
\hline Linear & $\begin{array}{l}-5.887 \\
(4.053)\end{array}$ & $\begin{array}{c}-11.271 \\
(9.667)\end{array}$ & $\begin{array}{c}-27.511 \\
(36.446)\end{array}$ & $\begin{array}{l}-7.545^{*} \\
(4.479)\end{array}$ & $\begin{array}{c}3.519 \\
(10.835)\end{array}$ & $\begin{array}{l}-25.057 \\
(39.700)\end{array}$ & $\begin{array}{c}-0.404 \\
(2.636)\end{array}$ & $\begin{array}{l}-5.971 \\
(6.476)\end{array}$ & $\begin{array}{c}18.545 \\
(18.637)\end{array}$ & $\begin{array}{c}7.124 \\
(10.355)\end{array}$ & $\begin{array}{c}4.802 \\
(25.217)\end{array}$ & $\begin{array}{c}81.022 \\
(75.314)\end{array}$ \\
\hline \multicolumn{13}{|c|}{ C: Mothers (low-SES) } \\
\hline Linear & $\begin{array}{l}-4.085 \\
(4.522)\end{array}$ & $\begin{array}{l}6.289 \\
\quad(24.253)\end{array}$ & $\begin{array}{c}3.235 \\
(70.302)\end{array}$ & $\begin{array}{l}-2.118 \\
(3.987)\end{array}$ & $\begin{array}{c}8.564 \\
(22.650)\end{array}$ & $\begin{array}{c}49.055 \\
(70.538)\end{array}$ & $\begin{array}{c}2.499 \\
(2.384)\end{array}$ & $\begin{array}{c}16.904^{*} \\
(9.671)\end{array}$ & $\begin{array}{l}7.219 \\
\quad(37.410)\end{array}$ & $\begin{array}{c}-21.434 * * \\
(9.663)\end{array}$ & $\begin{array}{c}-26.589 \\
(46.619)\end{array}$ & $\begin{array}{c}-78.451 \\
(127.972)\end{array}$ \\
\hline \multicolumn{13}{|c|}{ D: Mothers (high-SES) } \\
\hline Linear & $\begin{array}{l}-6.535 \\
(7.070)\end{array}$ & $\begin{array}{c}-0.622 \\
(20.740)\end{array}$ & $\begin{array}{c}3.568 \\
(61.950)\end{array}$ & $\begin{array}{l}-7.646 \\
(6.749)\end{array}$ & $\begin{array}{l}-11.802 \\
(22.165)\end{array}$ & $\begin{array}{c}26.935 \\
(73.106)\end{array}$ & $\begin{array}{c}-4.409 \\
(2.767)\end{array}$ & $\begin{array}{c}-5.377 \\
(12.418)\end{array}$ & $\begin{array}{c}13.491 \\
(30.686)\end{array}$ & $\begin{array}{l}14.640 \\
(9.943)\end{array}$ & $\begin{array}{c}31.183 \\
(32.753)\end{array}$ & $\begin{array}{c}22.285 \\
(93.628)\end{array}$ \\
\hline \multicolumn{13}{|c|}{ E: Fathers (low-SES) } \\
\hline Linear & $\begin{array}{c}-10.420^{* *} \\
(5.061)\end{array}$ & $\begin{array}{l}-20.641 \\
(14.818)\end{array}$ & $\begin{array}{c}-13.653 \\
(61.190)\end{array}$ & $\begin{array}{c}-12.555^{* *} \\
(5.293)\end{array}$ & $\begin{array}{c}-0.871 \\
(16.222)\end{array}$ & $\begin{array}{l}-25.233 \\
(60.506)\end{array}$ & $\begin{array}{c}-0.846 \\
(3.204)\end{array}$ & $\begin{array}{c}-11.582 \\
(9.434)\end{array}$ & $\begin{array}{c}35.499 \\
(22.538)\end{array}$ & $\begin{array}{c}4.003 \\
(15.344)\end{array}$ & $\begin{array}{c}-26.843 \\
(37.650)\end{array}$ & $\begin{array}{c}62.664 \\
(119.839)\end{array}$ \\
\hline Quadratic & & $\begin{array}{l}0.598 \\
\quad(0.861)\end{array}$ & $\begin{array}{l}-0.349 \\
(8.214)\end{array}$ & & $\begin{array}{l}-0.682 \\
(0.997)\end{array}$ & $\begin{array}{l}2.625 \\
\quad(8.250)\end{array}$ & & $\begin{array}{c}0.627 \\
(0.451)\end{array}$ & $\begin{array}{c}-5.756^{*} \\
(2.998)\end{array}$ & & $\begin{array}{c}1.810 \\
(2.186)\end{array}$ & $\begin{array}{l}-10.198 \\
(14.657)\end{array}$ \\
\hline Cubic & & & $\begin{array}{c}0.040 \\
(0.351)\end{array}$ & & & $\begin{array}{l}-0.140 \\
(0.353)\end{array}$ & & & $\begin{array}{c}0.270 * * \\
(0.131)\end{array}$ & & & $\begin{array}{c}0.503 \\
(0.575)\end{array}$ \\
\hline \multicolumn{13}{|c|}{ F: Fathers (high-SES) } \\
\hline Linear & $\begin{array}{c}2.330 \\
(5.379)\end{array}$ & $\begin{array}{l}7.621 \\
\quad(18.950)\end{array}$ & $\begin{array}{l}-62.491 \\
(65.060)\end{array}$ & $\begin{array}{c}0.152 \\
(4.197)\end{array}$ & $\begin{array}{c}14.324 \\
(13.565)\end{array}$ & $\begin{array}{l}-37.506 \\
(44.684)\end{array}$ & $\begin{array}{c}0.142 \\
(3.068)\end{array}$ & $\begin{array}{c}0.081 \\
(8.749)\end{array}$ & $\begin{array}{l}-10.383 \\
(27.432)\end{array}$ & $\begin{array}{c}9.713 \\
(7.931)\end{array}$ & $\begin{array}{c}37.843 \\
(26.532)\end{array}$ & $\begin{array}{c}60.104 \\
(104.459)\end{array}$ \\
\hline Quadratic & & $\begin{array}{l}-0.313 \\
(0.943)\end{array}$ & $\begin{array}{c}9.269 \\
(8.308)\end{array}$ & & $\begin{array}{c}-0.837 \\
(0.679)\end{array}$ & $\begin{array}{l}6.237 \\
\quad(5.852)\end{array}$ & & $\begin{array}{c}0.004 \\
(0.441)\end{array}$ & $\begin{array}{l}1.431 \\
\quad(3.387)\end{array}$ & & $\begin{array}{l}-1.671 \\
(1.469)\end{array}$ & $\begin{array}{c}-4.727 \\
(13.367)\end{array}$ \\
\hline Cubic & & & $\begin{array}{l}-0.407 \\
(0.346)\end{array}$ & & & $\begin{array}{l}-0.299 \\
(0.251)\end{array}$ & & & $\begin{array}{l}-0.060 \\
(0.136)\end{array}$ & & & $\begin{array}{c}0.131 \\
(0.543)\end{array}$ \\
\hline
\end{tabular}

Notes: The sample includes married or cohabiting mothers and fathers, respectively, who have coresident household children under age 19. Marginal

effects are estimated using Tobit models. Unemployment rates are measured at the state level and all specifications include state and year fixed effects and individual and household-level control variables. Minutes of paid work include any time spent on paid work or related activities. ATUS final weights are used. Standard errors adjusted for clustering by state are reported in parentheses.

*** Significant at 1 percent; $* *$ Significant at 5 percent; $*$ Significant at 10 percent 


\section{Figure 7. Time Spent on Paid Work Activities by Socioeconomic Status}

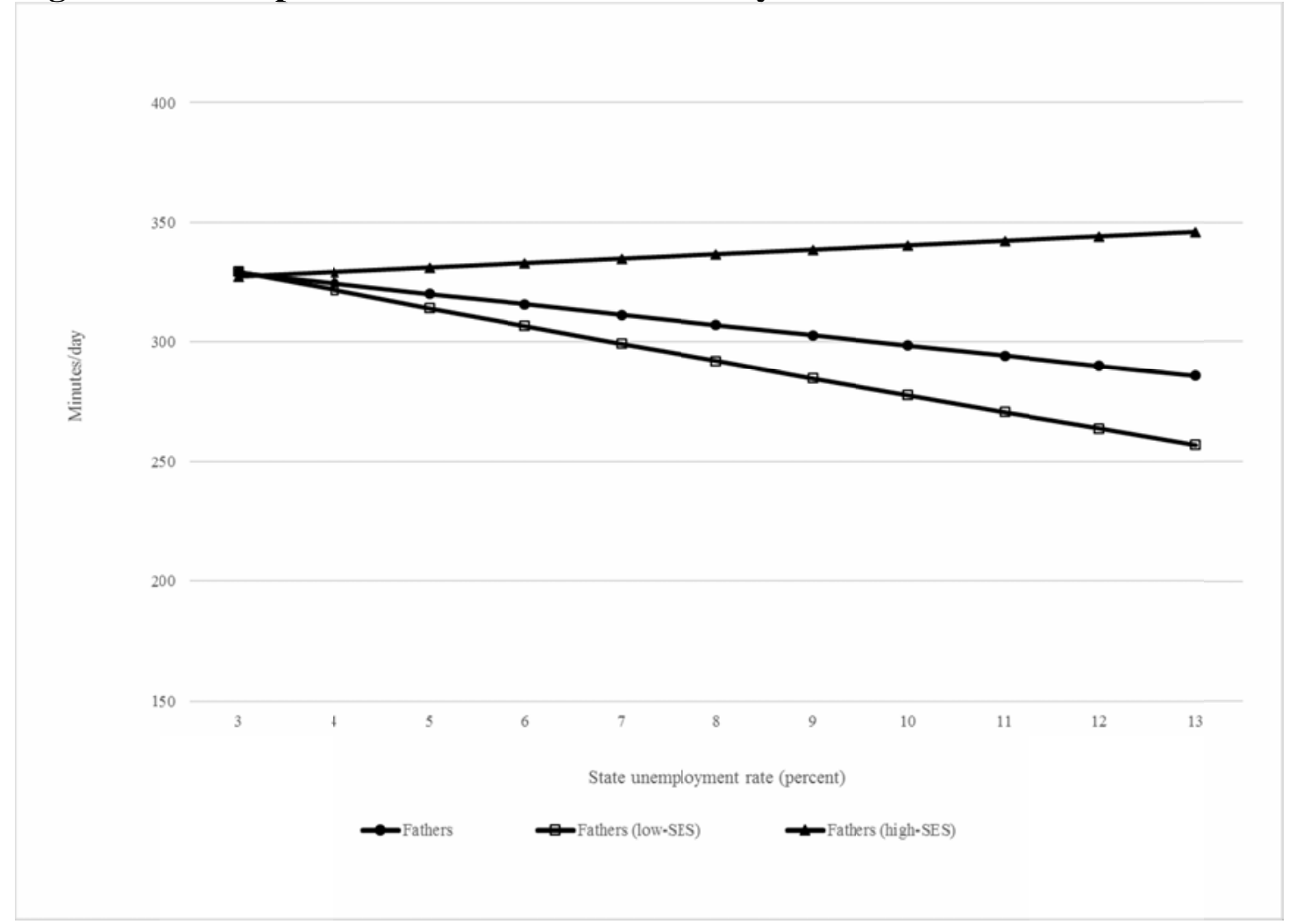

Notes: Figure 7 shows the predicted mean minutes spent on paid work with 95 percent confidence intervals and matches quadratic specifications in table 6 , panels $\mathrm{B}, \mathrm{E}$, and $\mathrm{F}$.

Table 7 shows the results by race and ethnicity. We find that paid work time and timing of work exhibit different patterns when the mothers' and fathers' samples are restricted by race and ethnicity. For white mothers, we find a cubic polynomial relationship between paid work time on the weekends and the unemployment rate, where white mothers' paid work time on the weekends is at its highest when the unemployment rate is at its lowest, and at its lowest when the unemployment rate is at its highest, with an increase between the unemployment rates of 6-10 percent (column 12, panel A). When the unemployment rate is at 10 percent, relative to when it is at 5 percent, white mothers work for pay for eight more minutes on the weekends. 
Table 7. Time Spent on Paid Work and Timing of Paid Work bv Race and Ethnicitv (in Minutes)

\begin{tabular}{|c|c|c|c|c|c|c|c|c|c|c|c|c|}
\hline \multirow{2}{*}{\multicolumn{2}{|c|}{$(1)$}} & \multicolumn{2}{|l|}{ All days } & \multicolumn{2}{|c|}{ Weekdays, 8 am to 6 pm } & \multicolumn{4}{|c|}{ Weekdays, 6 pm to 8 am } & \multicolumn{3}{|c|}{ Weekends } \\
\hline & & $(2)$ & (3) & (4) & $(5)$ & (6) & $(7)$ & $(8)$ & (9) & $(10)$ & $(11)$ & $(12)$ \\
\hline \multicolumn{13}{|c|}{ (A) White Mothers } \\
\hline Linear & $\begin{array}{c}3.320 \\
(5.513)\end{array}$ & $\begin{array}{c}18.759 \\
(17.548)\end{array}$ & $\begin{array}{l}-29.136 \\
(69.582)\end{array}$ & $\begin{array}{c}0.995 \\
(5.585)\end{array}$ & $\begin{array}{c}8.829 \\
(18.642)\end{array}$ & $\begin{array}{l}41.210 \\
(64.451)\end{array}$ & $\begin{array}{c}3.671 \\
(2.302)\end{array}$ & $\begin{array}{l}12.086 \\
(9.480)\end{array}$ & $\begin{array}{c}14.920 \\
(27.110)\end{array}$ & $\begin{array}{l}1.950 \\
(6.950)\end{array}$ & $\begin{array}{c}10.883 \\
(30.583)\end{array}$ & $\begin{array}{l}-160.090 \\
(112.242)\end{array}$ \\
\hline Quadratic & & $\begin{array}{l}-0.939 \\
(0.945)\end{array}$ & $\begin{array}{c}5.641 \\
(9.065)\end{array}$ & & $\begin{array}{l}-0.480 \\
(0.951)\end{array}$ & $\begin{array}{l}-4.949 \\
(8.177)\end{array}$ & & $\begin{array}{l}-0.514 \\
(0.575)\end{array}$ & $\begin{array}{l}-0.906 \\
(3.428)\end{array}$ & & $\begin{array}{l}-0.532 \\
(1.803)\end{array}$ & $\begin{array}{c}22.622 \\
(13.976)\end{array}$ \\
\hline Cubic & & & $\begin{array}{l}-0.282 \\
(0.372) \\
\end{array}$ & & & $\begin{array}{l}0.193 \\
(0.334) \\
\end{array}$ & & & $\begin{array}{c}0.017 \\
(0.139) \\
\end{array}$ & & & $\begin{array}{l}-0.981 * \\
(0.565) \\
\end{array}$ \\
\hline \multicolumn{13}{|c|}{ (B) African-American Mothers } \\
\hline Urate & $\begin{array}{l}-29.917^{*} \\
(16.933)\end{array}$ & $\begin{array}{c}89.117 \\
(59.905)\end{array}$ & & $\begin{array}{l}-14.607 \\
(19.933)\end{array}$ & $\begin{array}{c}145.435^{* * * *} \\
(56.114)\end{array}$ & & $\begin{array}{c}7.303 \\
(11.925)\end{array}$ & $\begin{array}{l}85.714 * * \\
(42.184)\end{array}$ & & $\begin{array}{c}-2.913 \\
(39.065)\end{array}$ & $\begin{array}{c}100.662 \\
(103.395)\end{array}$ & \\
\hline Urate $^{2}$ & & $\begin{array}{c}-7.509 * * \\
(3.455) \\
\end{array}$ & & & $\begin{array}{c}-10.126 * * * \\
(2.960)\end{array}$ & & & $\begin{array}{l}-5.003 * \\
(2.570)\end{array}$ & & & $\begin{array}{l}-6.348 \\
(6.077) \\
\end{array}$ & \\
\hline \multicolumn{13}{|c|}{ (C) Hispanic Mothers } \\
\hline Linear & $\begin{array}{c}-10.848 \\
(7.766)\end{array}$ & $\begin{array}{l}-67.617 \\
(54.401)\end{array}$ & $\begin{array}{c}105.676 \\
(163.496)\end{array}$ & $\begin{array}{l}-8.895 \\
(9.176)\end{array}$ & $\begin{array}{l}-68.391 \\
(43.159)\end{array}$ & $\begin{array}{r}-87.128 \\
(158.155)\end{array}$ & $\begin{array}{l}-3.948 \\
(4.804)\end{array}$ & $\begin{array}{l}-26.460 \\
(20.110)\end{array}$ & $\begin{array}{l}-64.410 \\
(77.368)\end{array}$ & $\begin{array}{c}-5.404 \\
(14.603)\end{array}$ & $\begin{array}{c}-75.195 \\
(114.116)\end{array}$ & $\begin{array}{l}788.427 * * \\
(327.072)\end{array}$ \\
\hline Quadratic & & $\begin{array}{c}3.308 \\
(2.922)\end{array}$ & $\begin{array}{l}-19.946 \\
(20.555)\end{array}$ & & $\begin{array}{c}3.479 \\
(2.199)\end{array}$ & $\begin{array}{l}5.991 \\
\quad(19.633)\end{array}$ & & $\begin{array}{c}1.316 \\
(1.108)\end{array}$ & $\begin{array}{c}6.416 \\
(10.132)\end{array}$ & & $\begin{array}{c}4.047 \\
(6.516)\end{array}$ & $\begin{array}{c}-111.560 * * * \\
(40.344)\end{array}$ \\
\hline Cubic & & & $\begin{array}{c}0.973 \\
(0.837) \\
\end{array}$ & & & $\begin{array}{l}-0.105 \\
(0.790)\end{array}$ & & & $\begin{array}{l}-0.214 \\
(0.425)\end{array}$ & & & $\begin{array}{c}4.839 * * * \\
(1.601) \\
\end{array}$ \\
\hline \multicolumn{13}{|c|}{ (D) White Fathers } \\
\hline Linear & $\begin{array}{l}-8.455^{*} \\
(4.576)\end{array}$ & $\begin{array}{c}-8.278 \\
(14.247)\end{array}$ & & $\begin{array}{l}-7.594 \\
(5.006)\end{array}$ & $\begin{array}{c}11.113 \\
(12.694)\end{array}$ & & $\begin{array}{l}-1.316 \\
(2.600)\end{array}$ & $\begin{array}{c}-15.965 * * \\
(6.400)\end{array}$ & & $\begin{array}{l}-10.010 \\
(10.250)\end{array}$ & $\begin{array}{c}-3.778 \\
(27.530)\end{array}$ & \\
\hline Quadratic & & $\begin{array}{l}-0.011 \\
(0.787) \\
\end{array}$ & & & $\begin{array}{l}-1.118 \\
(0.706) \\
\end{array}$ & & & $\begin{array}{c}0.876 * * \\
(0.356) \\
\end{array}$ & & & $\begin{array}{l}-0.372 \\
(1.405) \\
\end{array}$ & \\
\hline \multicolumn{13}{|c|}{ (E) African-American Fathers } \\
\hline Linear & $\begin{array}{c}20.047 \\
(23.069)\end{array}$ & $\begin{array}{c}-1.597 \\
(54.897)\end{array}$ & $\begin{array}{c}-61.477 \\
(158.266)\end{array}$ & $\begin{array}{c}8.471 \\
(19.549)\end{array}$ & $\begin{array}{c}2.595 \\
(50.600)\end{array}$ & $\begin{array}{l}-190.027 \\
(137.991)\end{array}$ & $\begin{array}{l}-11.046 \\
(10.586)\end{array}$ & $\begin{array}{l}-29.204 \\
(30.380)\end{array}$ & $\begin{array}{c}78.250 \\
(103.086)\end{array}$ & $\begin{array}{l}57.100^{*} \\
(33.885)\end{array}$ & $\begin{array}{c}129.539 \\
(119.662)\end{array}$ & $\begin{array}{l}-526.799 \\
(439.987)\end{array}$ \\
\hline Quadratic & & $\begin{array}{c}1.290 \\
(2.680)\end{array}$ & $\begin{array}{c}9.366 \\
(20.509)\end{array}$ & & $\begin{array}{c}0.351 \\
(2.583)\end{array}$ & $\begin{array}{l}26.190 \\
\quad(17.963)\end{array}$ & & $\begin{array}{c}1.084 \\
(1.576)\end{array}$ & $\begin{array}{l}-13.282 \\
(13.116)\end{array}$ & & $\begin{array}{l}-4.358 \\
(6.525)\end{array}$ & $\begin{array}{c}86.600 \\
(53.734)\end{array}$ \\
\hline Urate $^{3}$ & & & $\begin{array}{l}-0.338 \\
(0.877) \\
\end{array}$ & & & $\begin{array}{l}-1.074 \\
(0.733) \\
\end{array}$ & & & $\begin{array}{c}0.596 \\
(0.537) \\
\end{array}$ & & & $\begin{array}{l}-3.945^{*} \\
(2.153) \\
\end{array}$ \\
\hline \multicolumn{13}{|c|}{ (F) Hispanic Fathers } \\
\hline Urate & $\begin{array}{l}-12.218 \\
(10.023)\end{array}$ & $\begin{array}{l}-16.382 \\
(31.843)\end{array}$ & & $\begin{array}{c}-18.650^{* * * *} \\
(5.938)\end{array}$ & $\begin{array}{c}-8.816 \\
(22.703)\end{array}$ & & $\begin{array}{l}-1.012 \\
(4.163)\end{array}$ & $\begin{array}{c}21.769 \\
(15.869)\end{array}$ & & $\begin{array}{c}32.439 \\
(23.918)\end{array}$ & $\begin{array}{l}-95.137 \\
(66.508)\end{array}$ & \\
\hline Urate $^{2}$ & & $\begin{array}{c}0.240 \\
(1.761)\end{array}$ & & & $\begin{array}{c}-0.566 \\
(1.346)\end{array}$ & & & $\begin{array}{l}-1.308 \\
(0.820)\end{array}$ & & & $\begin{array}{l}7.361 * * \\
(3.716)\end{array}$ & \\
\hline
\end{tabular}

Notes: See notes to table 6. 
White fathers' total paid work hours decline linearly with an increase in the unemployment rate (column 1, panel D). For white fathers, we also find a nonlinear relationship between the unemployment rate and paid work time during nonstandard hours on weekdays, where an increase in the unemployment rate from 5 percent to 10 percent is associated with five fewer minutes of paid work (column 8, panel D). The statistically significant decline in white fathers' paid work hours, coupled with the increase in weekend paid work hours of white mothers when the unemployment rate is between 6 to 10 percent, is consistent with an added-worker effect among white mothers when the unemployment rate is between 6-10 percent. When the unemployment rate exceeds 10 percent, possibly due to fewer employment opportunities at these high unemployment rates, this effect disappears.

For Hispanic mothers we find a cubic relationship between the unemployment rate and paid work hours on the weekends, where Hispanic mothers spend 27 fewer minutes on paid work activities when the unemployment rate is at 10 percent compared to when it is at 5 percent (column 12, panel C). For Hispanic fathers, when we consider only the standard work hours on weekdays, we find that their paid work hours decline linearly with an increase in unemployment rates (column 4, panel F). We also observe a quadratic relationship between Hispanic fathers' weekend paid work hours and the unemployment rate, where an increase in the unemployment rate from 5 to 10 percent is associated with 25 more minutes of paid work time on the weekends (column 11, panel F). The changes in weekend paid work hours of Hispanic mothers and Hispanic fathers are consistent with a scenario where Hispanic mothers whose weekend paid work hours decline are now available to take on child-caregiving activities on the weekends. Meanwhile, fathers increase their paid work hours on the weekends. During standard hours on weekdays, Hispanic fathers spend less time on paid work activities.

For African-American mothers, we find a quadratic relationship between the unemployment rate and total paid work time, which we also observe in standard hours on weekdays and in nonstandard hours on weekdays (columns 2, 5, 8, panel B). An increase in the unemployment rate from 5 percent to 10 percent is associated with an hour less time spent on paid work activities for African-American mothers. Between these unemployment rates, we also see on a shift in paid weekday work hours from standard to nonstandard hours. Specifically, for African-American mothers, an increase in the unemployment rate from 5 percent to 10 percent is associated with 21 
fewer minutes of paid work during standard hours and 23 more minutes during nonstandard hours. This may be due to a decline in job opportunities during standard hours on weekdays when the economy worsens, and the jobs available are during nonstandard hours.

For African-American fathers we find a linear increase in weekend paid work hours with an increase in the unemployment rate, where African-American fathers work almost an hour more over the weekends when the unemployment rate increases by 1 percentage point (column 12, panel E). Compared to when it is at 5 percent, when the unemployment rate is at 10 percent, African-American fathers work two hours more on the weekends. These findings suggest the possibility that when African-American mothers' nonstandard paid work hours on the weekdays increase, fathers provide care for children while mothers are working for pay and mothers are with the children over the weekend while fathers (whose weekend paid work hours increased) are away. Taken together with the findings for African-American mothers and Hispanic fathers, our findings for African-American fathers show that when the unemployment rate is at 10 percent, African-American mothers and fathers and Hispanic fathers work longer nonstandard hours compared to when the unemployment rate is at 5 percent. Conversely, the nonstandard paid work hours of white fathers and mothers in low-SES households are shorter when the unemployment rate is at 10 percent. For white mothers, we observe an added-worker effect, while African-American mothers (whose total work hours decline) work more during nonstandard hours on weekdays and African-American fathers' paid work on the weekends increases. Weekend paid work hours decline for Hispanic mothers, and Hispanic fathers' weekend paid work hours increase by about the same amount.

\section{CONCLUSION}

In this study, we explored the relationship between state unemployment rates and the time mothers and fathers spent providing care for their children over the 2003-14 period. Our variables of interest are primary child-caregiving time, secondary child-caregiving time, solo time with children, and family time. 
Overall, we find that the relationship between these variables and the state unemployment rate tends to be more pronounced in low-SES households, which were defined as households in which the father does not have a college degree. Given that workers without a college degree experienced more job losses during the recession and faced higher income constraints than their counterparts, this finding suggests that the full sample results reflect the patterns of time use in households that experienced job loss or otherwise face greater income constraints. Similarly, we find that compared to their white counterparts, family time in African-American households and Hispanic households varies more with macroeconomic conditions. Our results suggest that the burden of household adjustment during the recession is a phenomenon that describes the experiences of low-SES households, as well as African-American and Hispanic households, compared to their respective counterparts.

Understood through Elson's (2010) analysis of the Great Recession through a gender lens, our findings show that in the reproductive sphere, the worsening of state macroeconomic conditions had gender- as well as race- and ethnicity-differentiated outcomes. Mothers' primary childcaregiving time does not decline significantly until the unemployment rate exceeds 10 percent, which is consistent with the role played by gender norms in shaping outcomes of the recession. We also find that fathers provide more primary child caregiving when the unemployment rate rises above 6 percent; however, our examination of fathers' primary child caregiving shows that this is more likely to be the case in households where mothers' paid work hours increase. Mothers' primary child-caregiving time and the solo time they spend with their children varies less with macroeconomic conditions compared to their secondary child-caregiving time and the time they spend as a family. Compared to fathers, mothers' spent time on primary and secondary childcare activities also varies less with the unemployment rate, which suggests that compared to fathers, mothers' time spent on these activities is less sensitive to changes in macroeconomic conditions.

We have explored the patterns in paid work hours and work schedules and find evidence of an added-worker effect in white households, where at high unemployment rates mothers work longer hours on the weekends. These patterns in paid work time coincide with an increase in fathers' primary and secondary child-caregiving time, while mothers' primary child-caregiving time remains unchanged. The increase in fathers' caregiving time is more pronounced in low- 
SES households compared to high-SES households. At higher unemployment rates, AfricanAmerican mothers' paid work hours are shorter, and we also observe a shift from standard to nonstandard hours on weekdays. African-American fathers work longer hours on the weekends at high unemployment rates. In African-American households, possibly due to more time together during standard hours on weekdays, family time increases when the unemployment rates exceeds 7 percent. In Hispanic households, time spent together as a family declines between the unemployment rates of 3 to 10 percent, and remains relatively unchanged when the unemployment rate exceeds 10 percent compared to the rates observed at unemployment rates of 2 to 10 percent.

In African-American, Hispanic, and white households, we observe complementary patterns of time use in the time mothers and fathers spent solo with children, suggesting that mothers and fathers are coordinating their paid work schedules in a way where one of them is with children. However, these adjustments are not as pronounced in white households or in high-SES households. Moreover, in Hispanic households these adjustments come at the expense of more family time together. Given the pronounced relationships between the unemployment rate and nonstandard work hours in African-American and Hispanic households, it is not surprising that we find that solo time on childcare activities varies more with the unemployment rate in these households.

The long-term effects of economic crises on children's well-being that have been discussed within the context of declining household income and other monetary effects should also include the impact on the time use of parents. Specifically, "economic scarring" literature that explores the long-term well-being consequences of economic crises should include the time parents spend with and caring for their children in their analyses (Irons 2009). That fathers spend more time providing secondary care may improve child outcomes, while less time spent by mothers in these activities may further contribute to the stress of the recession on family members. 
Future research that investigates the primary activities of mothers and fathers during their time with children would contribute to our understanding of how gender differences in unpaid work burdens vary with state macroeconomic conditions. This research would contribute to our understanding of gendered patterns of time use during economic crises, and may help inform work-life family reconciliation policies. 


\title{
APPENDIX
}

\section{Table A. Primary Childcare Activities and Codes}

\author{
030101 Physical care for household children \\ 030102 Reading to/with household children \\ 030103 Playing with household children, not sports \\ 030104 Arts and crafts with household children \\ 030105 Playing sports with household children \\ 030186 Talking with/listening to household children, includes 030106 (all years), 030107 (2003) \\ 030108 Organization \& planning for household children \\ 030109 Looking after household children (as a primary activity) \\ 030110 Attending household children's events \\ 030111 Waiting for/with household children \\ 030112 Picking up/dropping off household children \\ 030199 Caring for \& helping household children, not classified elsewhere \\ 030201 Homework (household children) \\ 030202 Meetings and school conferences (household children) \\ 030203 Homeschooling of household children \\ 030204 Waiting associated with household children's education \\ 030299 Activities related to household child's education, not classified elsewhere \\ 030301 Providing medical care to household children \\ 030302 Obtaining medical care for household children \\ 030303 Waiting associated with household children's health \\ 030399 Activities related to household child's health, not classified elsewhere \\ 040101 Physical care for nonhousehold children \\ 040102 Reading to/with nonhousehold children \\ 040103 Playing with nonhousehold children, not sports \\ 040104 Arts and crafts with nonhousehold children \\ 040105 Playing sports with nonhousehold children \\ 040186 Talking with/listening to nonhousehold children, includes 040106 (all years), 040107 (2003) \\ 040108 Organization \& planning for nonhousehold children \\ 040109 Looking after nonhousehold children (as primary activity) \\ 040110 Attending nonhousehold children's events \\ 040111 Waiting for/with nonhousehold children \\ 040112 Dropping off/picking up nonhousehold children \\ 040199 Caring for and helping nonhousehold children, not classified elsewhere \\ 040201 Homework (nonhousehold children) \\ 040202 Meetings and school conferences (nonhousehold children) \\ 040203 Home schooling of nonhousehold children \\ 040204 Waiting associated with nonhousehold children's education \\ 040299 Activities related to nonhousehold child's educ., not classified elsewhere \\ 040301 Providing medical care to nonhousehold children \\ 040302 Obtaining medical care for nonhousehold children \\ 040303 Waiting associated with nonhousehold children's health \\ 040399 Activities related to nonhousehold child's health, not classified elsewhere
}

Note: Activity codes from 2003-14 ATUS data files. 


\section{REFERENCES}

Aguiar, Mark, Erik Hurst, and Loukas Karabarbounis. 2013. "Time Use During the Great Recession: Dataset.” American Economic Review 103(5): 1664-96.

Albelda, Randy. 2014. 'Gender impacts of the 'Great Recession' in the United States.” In M. Karamessini and J. Rubery (eds.), Women and Austerity: The Economic Crisis and the Future of Gender Equality. New York: Routledge.

Antonopoulos, Rania, Kjong Kim, Thomas Masterson, and Ajit Zacharias. 2013. "Investing in care in the midst of a crisis: A strategy for effective and equitable job creation." In R. Antonopoulos (ed.), Gender Perspectives and Gender Impacts of the Global Economic Crisis. New York: Routledge.

Anxo, Dominique, Letizia Mencarini, Ariane Pailhé, Anne Solaz, Maria L. Tanturri, and Lennart Flood. 2011. "Gender differences in time use over the life course in France, Italy, Sweden, and the US." Feminist Economics 17(3): 159-95.

Benería, Lourdes, Günseli Berik, and Maria Floro. 2015. Gender, Development and Globalization: Economics as if all People Mattered, second edition. London: Routledge.

Benería, Lourdes, and Shelley Feldman. 1992. Unequal Burden: Economic Crises, Persistent Poverty, and Women's Work. Boulder, CO: Westview Press.

Berik, Günseli, and Ebru Kongar. 2013. "Time allocation of married mothers and fathers in hard times: The 2007-09 US recession." Feminist Economics 19(3): 208-37.

Bianchi, Suzanne M. 2011. "Family change and time allocation in American families." The Annals of the American Academy of Political and Social Science 638(1): 21-44.

Bianchi, Suzanne M., Vanessa R. Wight, and Sarah B. Raley. 2005. "Maternal employment and family caregiving: Rethinking time with children in the ATUS." Paper presented at the American Time Use Survey (ATUS) Early Results Conference, Bethesda, MD, December 9.

Boushey, Heather. 2016. The Economics of Work-Life Conflict. Cambridge, MA: Harvard University Press.

Bureau of Labor Statistics (BLS). 2014. "Women in the Labor Force: A Databook." Report 1049. Available at: http://www.bls.gov/cps/wlf-databook-2013.pdf.

—. 2016a. "Labor Force Statistics from the Current Population Survey." Available at: http://www.bls.gov/cps/cpsaat11.htm.

. 2016b. "National Compensation Survey: Employee Benefits in the United States." Available at: http://www.bls.gov/ncs/ebs/benefits/2016/ownership/private/table32a.pdf. 
Casper, Lynne, and Martin O’Connell. 1998. "Work, income, the economy, and married fathers as child-care providers." Demography 35(2): 243-50.

Christensen, Kimberly. 2015. "He-cession? She-cession? The Gendered Impact of the Great Recession in the United States." Review of Radical Political Economics 47(3): 368-88.

Connelly, Rachel, and Jean Kimmel. 2009. "Spousal influences on parents' non-market time choices." Review of Economics of the Household 7(4): 361-94.

- 2010. Time Use of Mothers in the United States at the Turn of the 21st Century. Kalamazoo, MI: W.E. Upjohn Institute for Employment Research.

- 2011. "The role of non-standard work status in parental caregiving for young children." Eastern Economic Journal 37: 248-69.

Dickerson vonLockette, Niki. 2014. "Race and Recession: A Comparison of the Economic Impact of the 1980s and 2007-09 Recessions on Non-College-Educated Black and White Men." In Martha A. Starr (ed.), Consequences of Economic Downturn: Beyond the Usual Economics. New York: Palgrave MacMillan.

Dymski, Gary, Jesus Hernandez, and Lisa Mohanty. 2013. "Race, gender, power, and the US subprime mortgage and foreclosure crisis: A meso analysis." Feminist Economics 19(3): 124-51.

Elson, Diane. 1991. Male Bias in the Development Process, second edition. Manchester, UK: Manchester University Press.

- 2010. "Gender and the global economic crisis in developing countries: a framework for analysis." Gender and Development 18(2): 201-12.

Ehrenreich, Barbara, and Dedrick Muhammad. 2009. “The Recession's Racial Divide.” The New York Times, September 12. Available at: http://www.nytimes.com/2009/09/13/opinion/13ehrenreich.html

Enchautegui, Maria. 2013. "Non-standard Work Schedules and the Well-Being of Low-Income Families.” Urban Institute Working Paper 26. Washington, DC: Urban Institute. Available at: http://www.urban.org/research/publication/nonstandard-work-schedules-and-wellbeing-low-income-families..

Folbre, Nancy. 2006. "Measuring care: Gender, empowerment, and the care economy." Journal of Population Economics 7(2): 183-99.

Folbre, Nancy, and Jayoung Yoon. 2007. "What is child care? Lessons from time-use surveys of major english-speaking countries." Review of Economics of the Household 5(3): 223-48. 
Fukuda-Parr, Sakiko, James Heintz, and Stephanie Seguino. 2013. "Critical and Feminist Perspectives on Financial and Economic Crises: Heterodox Macroeconomics Meets Feminist Economics.” Feminist Economics 19(3): 4-31.

Glynn, Sarah. 2014. "Breadwinning Mothers, Then and Now." Report. Washington, DC: Center for American Progress. Available at: https://cdn.americanprogress.org/wpcontent/uploads/2014/06/Glynn-Breadwinners-report-FINAL.pdf.

Grown, Caren, and Emcet Tas. 2014. "Gender equality in the U.S. labor markets in the 'Great Recession' of 2007-10.” In M.A. Starr (ed.), Consequences of Economic Downturn: Beyond the Usual Economics. New York: Palgrave Macmillan.

Hartmann, H., Elyse Shaw, and Rachel O'Connor. 2014. "Women and Men in the Recovery: Where the Jobs Are." IWPR Briefing Paper C426. Washington, DC: Institute for Women's Policy Research. Available at: http://www.iwpr.org/publications/pubs/women-and-men-in-the-recovery-where-thejobs-are-women-recover-jobs-lost-in-recession-in-year-five.

English, Ashley, Heidi Hartmann, and Jeffrey Hayes. 2010. “Are Women Now Half the Labor Force? The Truth about Women and Equal Participation in the Labor Force." IWPR Briefing Paper C374. Washington, DC: Institute for Women's Policy Research. Available at: http:/www.in.gov/icw/files/employment.pdf.

İlkkaracan, İpek. forthcoming. "Unpaid Work in Macroeconomics: A Stocktaking Exercise." In Rachel Connelly and Ebru Kongar (eds.), Gender and Time Use in a Global Context: The Economics of Employment and Unpaid Labor. New York: Palgrave MacMillan.

Irons, John. 2009. "Economic Scarring: The long-term impacts of the recession.” EPI Briefing Paper \#243. Washington, DC: Economic Policy Institute. Available at: http://www.epi.org/files/page/-/img/110209scarring.pdf.

Kalenkoski, Charlene, David Ribar, and Leslie Stratton. 2007. "The effect of family structure." Review of Economics of the Household 5(4): 353-84.

Karamessini, Maria, and Jill Rubery. forthcoming. "The Challenge of Austerity for Equality: A Consideration of Eight European Countries in the Crisis." In Rachel Connelly and Ebru Kongar (eds.), Gender and Time Use in a Global Context: The Economics of Employment and Unpaid Labor. New York: Palgrave MacMillan.

Kaya Bahçe, Seçil A., and Emel Memiş. 2013. "Estimating the impact of the 2008-09 economic crisis on work time in Turkey." Feminist Economics 19(3): 181-207.

Morrill, Melinda Sandler, and Sabrina Wulff Pabilonia. 2012. "What effects do macroeconomic conditions have on families' time together?" BLS Working Paper 454. Washington, DC: Bureau of Labor Statistics. Available at: https://www.bls.gov/ore/pdf/ec120030.pdf. 
- 2015. "What effects do macroeconomic conditions have on the time couples with children spend together?" Review of Economics of the Household 3: 791-814.

Nelson, Julie. forthcoming. "The Challenge of Indirect Care." In Rachel Connelly and Ebru Kongar (eds.), Gender and Time Use in a Global Context: The Economics of Employment and Unpaid Labor. New York: Palgrave MacMillan.

Nock, Steven L., and Paul W. Kingston. 1988. "Time with children: The impact of couples' work-time commitments." Social Forces 67: 59-85.

OECD. 2016. “OECD Family Database.” Available at: www.oecd.org/social/family/database.

Presser, Harriet B., and Amy G. Cox. 1997. "The Work Schedules of Low-Educated American Women and Welfare Reform." Monthly Labor Review 120(4): 25-34.

Pressman, Steven. 2014. "Inequality and Its Discontents: The Real Causes and Consequences of the Crisis." In Martha A. Starr (ed.), Consequences of Economic Downturn: Beyond the Usual Economics. New York: Palgrave MacMillan.

Rubery, Jill. 1988. Women and Recession. London: Routledge.

_. 2013. "From 'Women and Recession' to 'Women and Austerity': A Framework for Analysis.” In Maria Karamessini and Jill Rubery (eds.), Women and Austerity: The Economic Crisis and the Future for Gender Equality. London: Routledge.

Şahin, Aysegul, Joseph Song, and Bart Hobijn. 2010. "The unemployment gender gap during the 2007 recession." Current Issues in Economics and Finance 16(2): 1-7.

Schwartz, Lisa K. 2001. "Minding the Children: Understanding How Recall and Conceptual Interpretations Influence Responses to a Time-Use Summary Question.” Unpublished paper. Washington, DC: US Bureau of Labor Statistics. Available at: http://www.bls.gov/osmr/pdf/st010180.pdf.

Starr, Martha A. 2011. "Recession and the Social Economy." In Martha A. Starr (ed.), Consequences of Economic Downturn: Beyond the Usual Economics. New York: Palgrave MacMillan.

- 2014. "Gender, added-worker effects, and the 2007-2009 recession: Looking within the household." Review of Economics of the Household 12: 209-35.

US Department of Labor. n.d. "Family and Medical Leave Act.” Washington, DC: US Department of Labor. Available at: https://www.dol.gov/whd/fmla/

Wisman, Jon D., and Barton Baker. 2014. "Rising Inequality and the Financial Crises of 1929 and 2008." In Martha A. Starr (ed.), Consequences of Economic Downturn: Beyond the Usual Economics. New York: Palgrave MacMillan. 